4 nordon 



\section{Nordic Perspectives on Carbon Market Mechanisms}




\section{Nordic Perspectives on Carbon Market Mechanisms}

TemaNord 2011:505

(C) Nordic Council of Ministers, Copenhagen 2011

ISBN 978-92-893-2193-8

This publication is available as Print on Demand (PoD) and can be ordered on

www.norden.org/order. Other Nordic publications are available at www.norden.org/en/publications.

Nordic Council of Ministers

Ved Stranden 18

DK-1061 København K

Phone (+45) 33960200

Fax (+45) 33960202

www.norden.org

\section{Nordic Council}

Ved Stranden 18

DK-1061 København K

Phone (+45) 33960400

Fax (+45) 33111870

\section{Nordic co-operation}

Nordic co-operation is one of the world's most extensive forms of regional collaboration, involving Denmark, Finland, Iceland, Norway, Sweden, and three autonomous areas: the Faroe Islands, Greenland, and Åland.

Nordic co-operation has firm traditions in politics, the economy, and culture. It plays an important role in European and international collaboration, and aims at creating a strong Nordic community in c strong Europe.

Nordic co-operation seeks to safeguard Nordic and regional interests and principles in the global community. Common Nordic values help the region solidify its position as one of the world's most innovative and competitive. 


\section{Content}

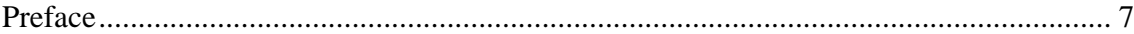

Nordic Perspectives on Carbon Market Mechanisms ................................................... 7

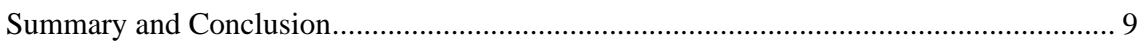

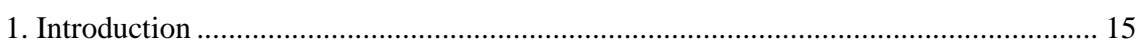

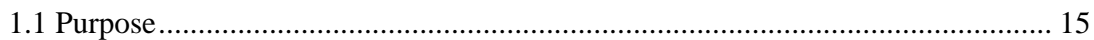

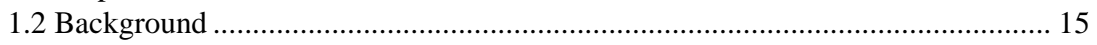

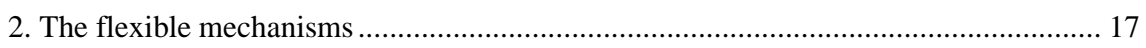

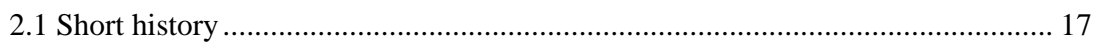

2.2 The Development of the Carbon market 2000-2010 ............................................ 18

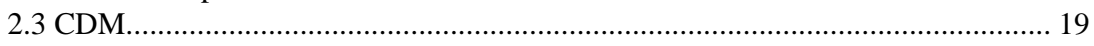

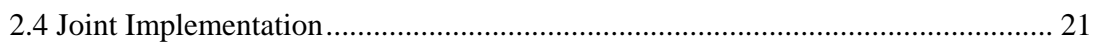

2.5 EU Policies and Regulations ............................................................................. 23

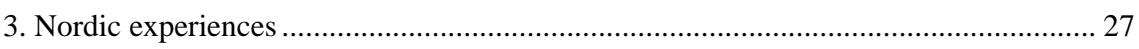

3.1 Nordic CER and ERU Purchasing Programs..................................................... 27

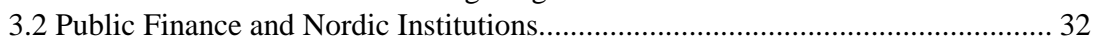

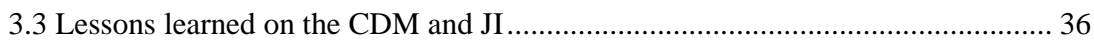

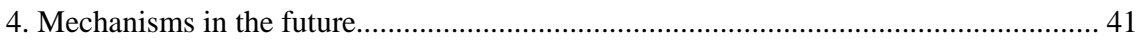

4.1 Improving CDM Approval Process ................................................................. 41

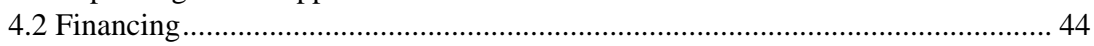

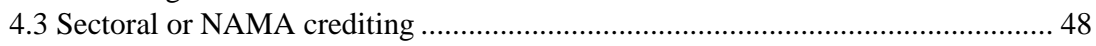

5. Forest and plantation related activities to reduce GHG emissions................................ 55

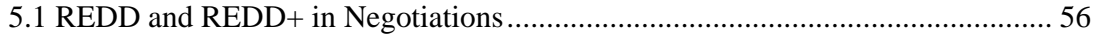

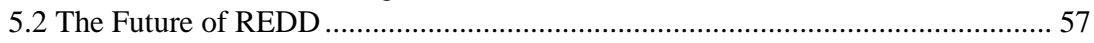

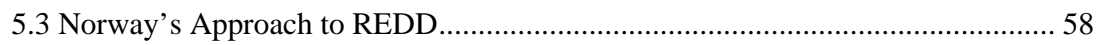

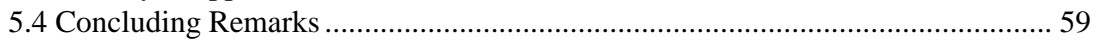

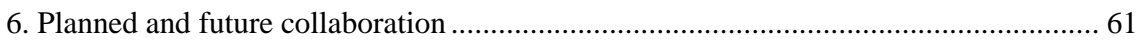

6.1 Nordic Collaboration Aiming at Improving Current

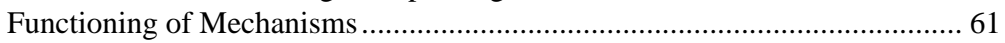

6.2 Continued Nordic Collaboration on Sharing of Practical

Experiences Related to National Purchase Programmes .................................. 61

6.3 Nordic Collaboration Aiming at the Development of New Mechanisms ............... 62

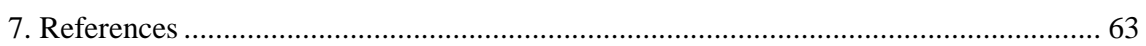

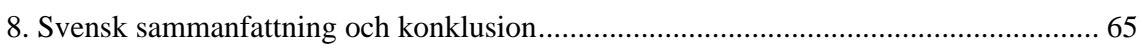





\section{Preface}

\section{Nordic Perspectives on Carbon Market Mechanisms}

The Nordic Council of Ministers appointed, via the Globalization Initiative, the Nordic finance ministers to launch a joint Nordic project regarding the international carbon market. The purpose of the project was to identify and exchange Nordic experiences from the Joint Implementation and Clean Development Mechanism credit market as well as to discuss prospects for future cooperation. The result of the project is presented in three reports from workshops held during 2010, as well as this synthesis report that summarizes previous reports.

The project was initiated in light of the expected negotiations on the future mechanisms after 2012 in COP 15, including as input for discussions on opportunities and prospects for participation in a future carbon market. The results have been presented at the meetings of the Nordic Council of Energy, Environment and Finance ministers during October and November 2010.

The project was prepared by a steering committee with the following members: Jon Kristian Pareliussen representing Norway, Olle Björk, Ulrika Raab and Ola Hansén representing Sweden, Juhani Tirkkonen and Outi Honkatukia representing Finland, Helga Bardadottir representing Iceland, Ola Yndeheim representing the Nordic Council of Ministers, Ash Sharma representing the Nordic Environment Finance Corporation as well as Martin Bo Hansen, Lykke Mulvad Jeppesen, Annette Norling and finally Ulla Blatt Bendtsen, representing Denmark and also chair of the steering group.

Vattenfall Power Consultant AB has been consultants on the assignment and served as secretariat for the steering group. The Steering Committee members have been active in providing information on the Nordic JI/CDM programmes, commenting on the reports and suggesting the outcome. These efforts are highly appreciated. Nevertheless, the information presented in this report and the underlying Workshop reports remain the sole responsebility of the Consultant. 



\section{Summary and Conclusion}

In August 2009, The Nordic Council of Ministers appointed the Nordic finance ministers to launch a joint project on the Nordic countries' experiences from Kyoto flexible mechanisms CDM (Clean Development Mechanism) and JI (Joint Implementation). The project was initiated in light of the expected negotiations of the future mechanisms after 2012, in order to give input to discussions on prospects and opportunities for the Nordic countries to participate in a future carbon market. The project has been implemented from April to September 2010, during which three workshops were executed, with participants from the Nordic governments, NEFCO, Nordic Financial and Development institutions, as well as special invitees from external organisations and companies. The first workshop treated the experience from Nordic CDM and JI purchase programmes, the second treated financing-related barriers towards implementing CDM and JI projects, and the third workshop treated potential future flexible mechanisms, and, moreover, a discussion on future cooperation between Nordic governments within the context of the future carbon market. The outcome of these three workshops is presented in three separate workshop reports, and this synthesis report summarizes the overall project results.

\section{Nordic Participation in the Carbon Market}

The carbon market has shown a tremendous growth the last decade, building on the flexible mechanisms that were launched with the Kyoto Protocol. The carbon market as a whole is expected to be worth $€ 121$ billion in 2010, corresponding to emission allowances of 8.4 Gtonnes of $\mathrm{CO} 2$ equivalents. The EU Emission Trading System, EU ETS, accounts for roughly 75\% of that volume.

The total amount of project-based transactions ${ }^{1}$ in the CDM market in 2009 was $211 \mathrm{Mt} \mathrm{CO}_{2}$, at an approximate value of $€ 1,916$ million $^{2}$, which was only about half of the value of this market in 2008. Project-based transactions in the JI market in 2009 were roughly $13 \%$ of the size of the CDM project-transactions, $26 \mathrm{Mt} \mathrm{CO}_{2}$, at an approximate value of $€ 252$ million $^{3}$.

As early participants in this market, the Nordic governments have contributed to the development of the carbon market, and in particular to the

\footnotetext{
${ }^{1}$ Project-related trasactions does not include transactions of secondary Kyoto offsets or spot transactions. Data on all transctions can be found in chapter 2 of the report.

${ }^{2}$ State and Trends of the carbon market 2010, report from The world Bank

${ }^{3}$ State and Trends of the carbon market 2010, report from The world Bank
} 
creation of a functioning market for CERs ${ }^{4}$ and ERUs ${ }^{5}$, which are the carbon credits resulting from the Kyoto flexible mechanisms CDM (Clean Development Mechanism) and JI (Joint Implementation), respectively. Overall, the Nordic countries have earmarked more than $€ 1$ billion for the government purchase of Kyoto offsets ${ }^{6}$, and for this amount the purchase programmes expect to receive a total of 60-75 million emission reduction units. The Nordic CDM- and JI purchase programmes have generally provided a cost-effective complement to national climate change strategies and reduction interventions.

The contribution to market development and trust in the market has paved the way for private companies, consultancies and brokers to enter the market. The contribution has consisted of various activities:

- The Nordic governments were among the first to engage in various carbon funds that were pioneers in the identification of projects, developing of new methodologies, and spreading knowledge of the CDM globally. Among the funds can be mentioned especially the World Bank Prototype Carbon Fund, which was the first launched carbon fund, and the Baltic Sea Region Testing Ground Facility, TGF, managed by NEFCO;

- The Nordic governments were among the first to establish own CDM and JI purchase programmes. Finland established, as the first Nordic country, an application for flexible mechanisms in 1999, Sweden followed in 2002, Denmark in 2003 and Norway in 2007. Several Nordic countries were thus identifying and developing CDM- and JI projects, in the early days of the carbon market when the process was most uncertain and few examples of success were available;

- The Nordic governments have conducted several capacity building programmes in order to increase the number of CDM and JI projects in countries that are or have been underrepresented in the carbon market.

The purpose of the CDM and JI purchase programmes of the Nordic governments are somewhat different. The Swedish programme does not have a volume target, while the programmes of the other Nordic countries do have volume targets. Denmark and Finland buy emission reduction units to meet their Kyoto commitments. Norway buys Kyoto offsets to over-fulfil its Kyoto commitment by 10 per cent. Sweden expects to meet its Kyoto commitments without use of Kyoto offsets, but may use these credits to meet future commitments. The goal of the Swedish purchase programme is thus more qualitative than quantitative, and supports the development of a global market, geographically spread with special focus on Least Developed Countries and Small Island Development States.

\footnotetext{
${ }^{4}$ Certified Emission Reductions, CERs

${ }^{5}$ Emission Reduction Units, ERUs

${ }^{6}$ Kyoto offsets are here defined as ERUs (Emission Reduction Units) and CERs (Certified Emission Reductions), the JI and CDM commodities.
} 
The methods used for purchasing vary among the Nordic countries and NEFCO, and purchase programme officials have exchanged experience on barriers and ways of overcoming barriers in all issues of the JI/CDM project cycle.

Lessons learned include the importance of using networks of organizations such as embassies, governmental investment funds, CDM/JI developers (i.e. private companies specialized in developing the CDM/JI component of a project or investment), the importance of good networking relations with host country DNAs, brokers, financial institutions and regular contact with DOEs. An established network and good reputation is helpul in order to identify and to manage follow up of projects. For example, it was perceived that NEFCO's relative success in the Baltic countries was due to long standing presence and reputation in the market. Commonly experienced barriers were often related to the validation/registration and verification/issuance phases, but also the implementation of small-scale projects in Least Developed Countries.

All programs had faced barriers with regard to the underlying financing of projects, e.g. it had proven to be challenging for project owners to use the Emission Reduction Purchase Agreement as collateral for loans or bank guarantees for advance payments, especially for projects owners in Least Developed Countries. The need for advance payment is especially large in renewable energy projects, since these projects often require a large investment in advance of cash flow from energy/electricity generation and CER delivery. In sum, the programs have contributed to the build up of the international carbon market, and the programs have provided valuable insights to the governments, insights that could be used in the UNFCCC negotiations related to CDM, JI and other potential future flexible mechanisms. Collaboration between Nordic countries on carbon market issues has created a good Nordic platform in the international climate negotiations. The purchase programs are also a cost-efficient way for countries to fulfill their Kyoto obligation while at the same timing providing for technology transfer and sustainable development in host countries, and for Norway a way to reach national targets that go beyond Kyoto Protocol commitments.

\section{Develop and Enhance Public Finance for CDM-Projects}

Investment costs in developing country projects are covered by equity and debt as in any project not involving carbon finance. Through CDM and JI owners and implementers of projects that mitigate green housegas emissions can receive an additional contribution to the overall financing of the projects. This financial contribution is generally in the form of an additional cash flow paid regurlary once the project is put into commercial operation, but can in some cases be partly paid in advance. A project owner should be able to use a forward CDM or JI contract as a collateral security in the loan 
application. However, even if CDM and JI contribute to the overall financing of the projects there is in general always a need for initial funding, i.e. equity and debt, which only partly can be removed by CDM and JI. As a result CDM and JI alone can only to limited extent increase the number of implemented projects in regions and countries where the investment climate is poor, e.g. Least Developed Countries, (LDCs). Public funding, such as from multilateral funds or through bilateral development assistance can override the strict requirements for investment returns of private capital, and can assume greater risk. Public finance therefore has an important and significant role both in relation to capacity building, project development and risk management, in the form of guarantees. Early development funding has not increased significantly with the CDM. Public financing can help to increase the supply of sustainable projects in under-represented sectors and countries, thus strengthening the interest from private investors to move into new regions as well as project types in of the carbon market.

The recently established ProClimate Facility by the Nordic Development Fund, NDF, is an initiative that provides publicly backed guarantees, which improves the financial leverage of a CDM contract. It is recommended that the Nordic countries launch a CDM pilot project in an African LDC country for the experience of the ProClimate guarantee facility.

Public finance can play an important role in improving the JI/CDM mechanisms, making the markets more effective, and breaking new ground for the CDM in Least developed Countries as well as in developing the market for new up-scaled mechanisms.

\section{Developing and Enhancing Existing and New Mechanisms in a Post 2012 Period}

The current framework with emissions trading and project-based mechanisms is the basis on which to form future mechanisms. The other main basis is the demand for scaled-up efforts in the developing countries. However, the slow pace and strong lines of conflict in the international negotiations over a post-2012 climate regime impose uncertainty regarding the carbon market. A continuation of a Kyoto-like system with CDM and JI as well as a broad agreement that incorporates new mechanisms can benefit from development and testing of new versions and designs of project-, program- or sector- or NAMA-based mechanisms. Reducing emissions from deforestation and forest degradation, as well as creating incentives for a sustainable forest management and the enhancement of carbon stocks are also essential for reaching the reduction targets proposed by the IPCC. Norway has taken a leading role in launching REDD pilot activities, particularly through financing initiatives. 
Concretely, the Nordic countries can act collectively in the following areas:

Firstly, CDM and potentially also JI will be very important mechanisms in the period up to 2020.

The revised EU ETS Directive (art. 11a, para.3) allowes exchange of both CDM and JI credits from projects registered before 2013 issued in respect of emission reductions from 2013 onwards. In the case of ERUs, issuance is subject to prior conversion of AAUs and absence of a second commitment period under the Kyoto Protocol would hinder continuation of JI projects after 2012. Continued issuance and transfer of ERUs could however be ensured after 2012 via bilateral agreements with Host Parties, in case these are not part of EU ETS. ERUs could also be generated by the recognition of projects under article 24a of the EU ETS Directive, in case projects are located in EU countries and fall outside the scope of ETS. The implementation of art. 11a para.3 still remains to be decided upon by the EU Commission. Initiatives on bilateral agreements with parties outside the EU ETS could be an effective way of strengthening JI after 2012 .

Initiatives aiming at improving CDM market conditions could have a positive impact on the number of new projects implemented and the geographical distribution of such projects. The ProClimate Facility and other similar initiatives underway could have a significant positive impact of the financial leverage of CDM contracts and be good basis for Nordic cooperation.

There is a need to make the CDM project cycle more efficient. Enhancing standardized baselines is one area that could boost the CDM and an area where also the Nordic countries could promote action by assisting in project development using standards. Standardization could increase the objectivity of additionally demonstration, objectivity and simplicity of baseline selection, as well as simplicity of emission calculations and monitoring. Standardized baselines are also seen as a way to ensure the environmental integrity of the CDM and to improve the geographical distribution of CDM project activities.

A standardized baseline approach could work within the renewable energy, transport, agriculture and energy efficiency in buildings sectors. The different types of standardizations to be used can be arranged under (i) positive list, (ii) emissions or performance benchmarks, (iii) technology penetration benchmarks and (iv) default factors and values.

Conducting future and existing capacity building programmes where grid emission factors are developed is another area that could boost the CDM, especially in countries that are underrepresented in the carbon market, and an area where also the Nordic countries have a potential to co-operate:

Firstly, efforts to make the existing mechanisms work more efficiently can be an effective way of getting acceptance for discussing new upscaled mechanisms within the UNFCCC fora. 
Secondly, new upscaled mechanisms, sectoral or $\mathrm{NAMA}^{7}$ crediting and/or trading, could be launched within the framework of UNFCCC and a global agreement. It is hoped that modalities and procedures for such a mechanism can be established within the coming years but, a full scale operation of such mechanisms is not likely before 2020 . There is thus a need for immediate action to facilitate negotiations and to develop the design of new mechanisms.

Any activities would need to consider that new mechanisms would need to be tailored to the political/economic realities in each country. There will be a need for good quality data, establishment of MRV (Measurement, Reporting and Verification) systems and policy development capacity in the developing countries. Beyond the developing country level, several issues are important for successful implementation of sectoral and/or NAMA crediting mechanisms. The difficulty of establishing baselines and reference levels must be overcome and new mechanisms must be designed in a way to keep and increase the incentive for private sector participation.

The Nordic Council of Ministers (through the Nordic Ad Hoc Group on Climate Change, NOAK) in cooperation with NEFCO will launch a feasibility study of a pilot, not under the title of a sectoral of NAMA crediting project, but of an upscaled sectoral credit mechanism. The project outline will be presented at COP 16 in Cancun in December 2010 under the title of the NOAK-NEFCO Partnership Initiative. One possible area of Nordic cooperation would be to take part in a testing facility that could be created under the wings of NEFCO in order to buy credits from pilot projects in the area of upscaled mechanisms or sectoral/NAMA crediting.

The benefits of implementing new mechanisms in developing countries are, except the contribution to globally reduced emissions, that the development of activities in the climate change sector may provide a foundation for strengthening the capacity of developing countries to conduct environmental policies and to provide for a transition to domestic developing country action including market based solutions such as trading schemes.

The framework for future Nordic cooperation still remains to be decided upon; bilateral discussions and informal contacts could develop into a formalized group for cooperation or cooperation could be more ad hoc as a part of NEFCO activities. The activities on which to cooperate on are of high priority and while the regulatory framework is still in the starting blocks, pilot activities and collaborative efforts, such as the NOAK-NEFCO Partnership Initiative, could have a significant positive impact on the negotiation process and the design of the new mechanisms.

\footnotetext{
${ }^{7}$ National Appropriate Mitigation Actions
} 


\section{Introduction}

\subsection{Purpose}

Autumn 2009, The Nordic Council of Ministers appointed the Nordic finance ministers to launch a joint project on the Nordic countries' experiences from Kyoto flexible mechanisms CDM (Clean Development Mechanism) and JI (Joint Implementation). The project was initiated in light of the expected negotiations of the future mechanisms after 2012, and aims to form input for discussions on prospects and opportunities for the Nordic countries to participate in a future carbon market.

\subsection{Background}

The Nordic Council of Ministers through the Nordiska samarbejdskommittén, NSK, agreed at a meeting on 1 October 2009 to launch a project that would explore these perspectives following the COP-15 in Copenhagen in December 2009. The scope of the project included but was not limited to the following issues:

- Nordic countries' experiences so far from the carbon market. Identify and communicate lessons learnt, results of different procurement channels, volume targets, administration responsibilities, national priorities and mandates, procurement strategies for JI/CDM, successes and failures in terms of technologies and project types, regions, public or private project owners;

- Views on Nordic co-operation in the market in the post-2012 period. Discuss in what areas Nordic institutions, bilateral financial institutions, export credit agencies, etc, could add value and play a role;

- Discuss if the Nordic experience could be used to inform the global negotiations on the design of the post-2012 carbon mechanisms;

- Discuss future kinds of crediting, including possible project types and regional distribution. Discuss priorities on projects or programmes and the experience that has been gained from trying to develop sector or up-scaled crediting via facilities as the Carbon Partnership Facility of the World Bank.

The project has been prepared by a steering committee with representatives from the Nordic JI and CDM authorities, representatives from the Nordic Ministries of Finance, from the Nordic Council of Ministers and NEFCO (the Nordic Environment Finance Corporation) and with Denmark as the 
Chairman. Vattenfall Power Consultant has acted as secretariat for the project steering group and has also provided background texts as well as presentations. The work has been channeled through three workshops:

1. "Exchange of experience and lessons learnt in the Nordic JI/CDM government procurement programs”. The workshop was held in Helsinki the 26 March 2010, hosted by NEFCO and the Finish Ministry of Employment and Economy. The participants consisted of the steering group and representatives from the government purchase programs.

2. “JI/CDM project financing and up-front payment guarantees". The workshop was held in Helsinki the 6 May 2010 and hosted by

NEFCO. Participating in the workshop were representatives from export guarantee funds, development financing institutions, private finance, multilateral finance organizations as well as development agencies.

3. "Perspectives for future co-operation on JI/CDM with focus on post2012 and new mechanisms”. The workshop took place in Oslo the 2 September 2010, hosted by the Norwegian Ministry of Finance. In addition to presentations by steering group members and the consultant, CCAP presented their work on NAMAs and Ecosecurities gave an introduction to standardized baselines.

The three workshops have been summarized in three separate workshop reports, mentioned in the list of references to this report.

This report firstly gives and introduction to the flexible mechanisms Clean Development Mechanism (CDM) and Joint Implementation (JI), the international policies and regulations as well as a brief introduction to EU specific requirements for the mechanisms (Chapter 2). The first section is followed by a summary of the Nordic activities within the frame of the current mechanisms (Chapter 3).

The third chapter of the report outlines the improvement agenda of the current mechanisms and proposals for new mechanisms (Chapter 4). This part is followed by a brief overview of current status and future of forestry and plantation projects related to REDD, Reducing Emissions from Deforestation and Degradation, (Chapter 5). Finally the last chapter of the report outlines planned and proposed initiatives for Nordic countries relating to improvement as well as upscaling of CDM and JI (Chapter 6).

This report contains a summary of the discussions and work conducted within the three workshops. The report does not provide in depth information and analyses of the issues touched upon during the whole project, but summarizes the issues and further steps for the Nordic countries in this area that were discussed during the workshops. 


\section{The flexible mechanisms}

\subsection{Short history}

The three so called flexible mechanisms: Joint Implementation (JI), Clean Development Mechanism (CDM) and International Emissions Trading (IET) introduced by the Kyoto Protocol aim to limit the global cost of mitigation by increasing the flexibility in how and where parties with legally binding quantified emissions reduction targets can reduce emissions. The design of the flexible mechanisms builds upon earlier experiences with Activities Implemented Jointly (AIJ), a convention instrument designed to gain experience with the carbon market. The Nordic countries have participated in the creation of the carbon market since the AIJ period.

The project based mechanisms CDM and JI were defined in the Kyoto Protocol and detailed rules and guidelines were established with the Marrakech Accords in 2001. The first meeting of the CDM Executive Board, which is the international body overseeing the CDM, took place in New Delhi 2002 during the climate change conference.

The Marrakech Accords created a prompt start for CDM, meaning that projects that were initiated before the start of the first commitment period of the Kyoto Protocol would be eligible for CDM and thus being able to generate carbon credits (Certified Emission Reductions, CERs) as from 2001, which was not possible for JI. The EU took on the ideas of emissions trading from the Kyoto Protocol negotiations and decided to launch a regional EU emissions trading scheme. This decision resulted in adopting legislation during the early 2000, and a pilot phase started in 2005. Given the prompt start of CDM, CERs could also be used by installations in the EU ETS during the first phase 2005-2007. Thus, already in 2005, both Emissions Trading and the CDM were in operation. Initiatives with regard to JI were also taken, and some countries, notably the Netherlands, launched a programme addressing JI mainly in Russia but also other parts of Easter Europe.

During the last years, CDM has grown significantly, JI has come into operation, and several countries are or are planning to establish emissions trading schemes. 


\subsection{The Development of the Carbon market 2000 - 2010}

The carbon market as a whole is expected to have a value of $€ 121$ billion in 2010, corresponding to emission allowances of 8.4 Gtonnes of CO2 equivalents ${ }^{8}$. The EU ETS roughly makes up $75 \%$ of that volume with the CER market expected to land at $20 \%$. The table below displays traded volumes of the European allowances (EUAs), the CDM reduction units CERs (Certified Emission Allowances) and the JI reduction units ERUs (Emission Reduction Units) in 2008, 2009, and forecasts for 2010, 2011 and 2012. Traded volumes include project-based transactions, spot and trading of secondary Kyoto offsets.

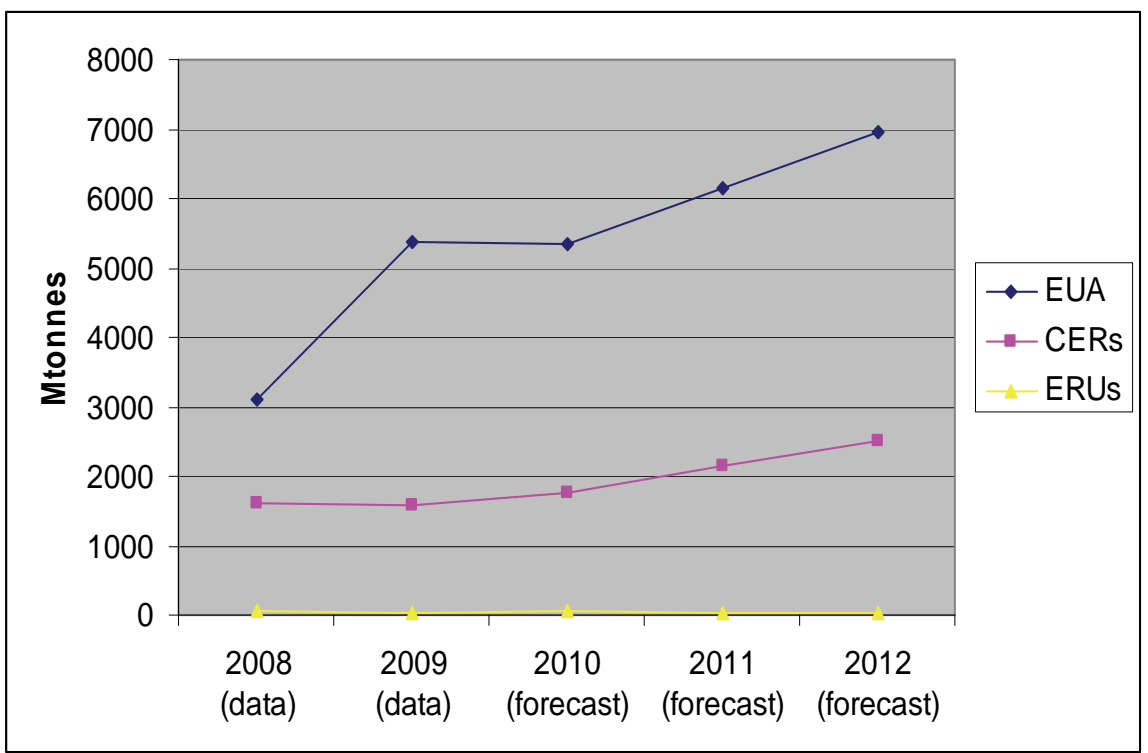

Figure 1. Traded volumes in the carbon market. All data from Point Carbon, Carbon Market Analyst, 27, 2010.

The EU's emission trading system, ETS, covers more than 12,000 facilities that produce energy or goods ranging from paper to cement. Polluters must have an allowance for each ton of carbon dioxide they emit when burning fossil fuels. Those producing more than their allowance must buy more, those that emit less can sell thir surplus. The EU aims to make the ETS, started in 2005, the cornerstone of a global carbon market. The 27-nation bloc seeks to cut greenhouse gases $20 \%$ by the end of this decade compared with 1990 levels and has claimed it may boost that target to 30\% should other countries take on comparable efforts.

\footnotetext{
${ }^{8}$ Point Carbon, Outlook for 2010 and Beyond,
} 


\section{$2.3 \mathrm{CDM}$}

\subsubsection{Introduction to the CDM}

The Clean Development Mechanism (CDM), defined in Article 12 of the Kyoto Protocol, allows a country with an emission reduction or emission stabilisation commitment under the Kyoto Protocol (Annex I) to implement an emission reduction project in a developing country (non-Annex I). Such projects can result in saleable certified emission reduction (CER) credits, each equivalent to one tonne of $\mathrm{CO}$, which can be counted towards meeting Kyoto targets.

A CDM project activity might involve, for example, a rural electrification project using solar panels, avoiding methane emissions from landfills, the construction of a hydropower plant instead of a coal fired one or the installation of energy-efficient boilers.

The mechanism stimulates sustainable development and emission reductions, while giving industrialized countries some flexibility in how they meet their emission reduction or limitation targets, allowing them to use carbon off-sets to supplement domestic abatement measures. Additional important benefit is the technology transfer to developing countries. In reality, there is large variation regarding the fulfilment of these additional goals, depending on project type and region.

A CDM project must provide emission reductions that are additional to what would otherwise have occurred, i.e. the project implementation should result in lower emission comparing to business as usual scenario. The project has to successfully qualify through a rigorous public registration and CER issuance process, all governed by the CDM Executive Board. Before the project can apply for the registration, it should be approved by the host country Designated National Authority (DNA) that assures the project's compliance with national sustainable development policy. Public funding for procurement of carbon credits must not result in the diversion of official development assistance, since this would limit the net contribution of development assistance.

The process leading up to registration and issuance of CERs is depicted in Figure 2. There is distinction between the primary and secondary market for CERs. The involvement of a purchaser of CERs during any of the steps before issuance is referred to as the primary market. Compliance buyers (for example energy utilities as Vattenfall, ENEL and RWE) and carbon finance brokers (Ecosecurities, Tricorona, Camco etc) sign forward contracts with project owners, taking the risks of validation, registration and issuance and receive CERs at delivery at a price below the secondary market price for CERs.

The mechanism is overseen by the Clean Development Mechanism Executive Board (CDM EB) answerable ultimately to the countries that have ratified the Kyoto Protocol and has been operational since the beginning of 2002. The mechanism has already registered more than 1,000 projects and 
is anticipated to produce CERs amounting to more than 2.9 billion tonnes of $\mathrm{CO} 2$ equivalent in the first commitment period of the Kyoto Protocol, 2008-2012.

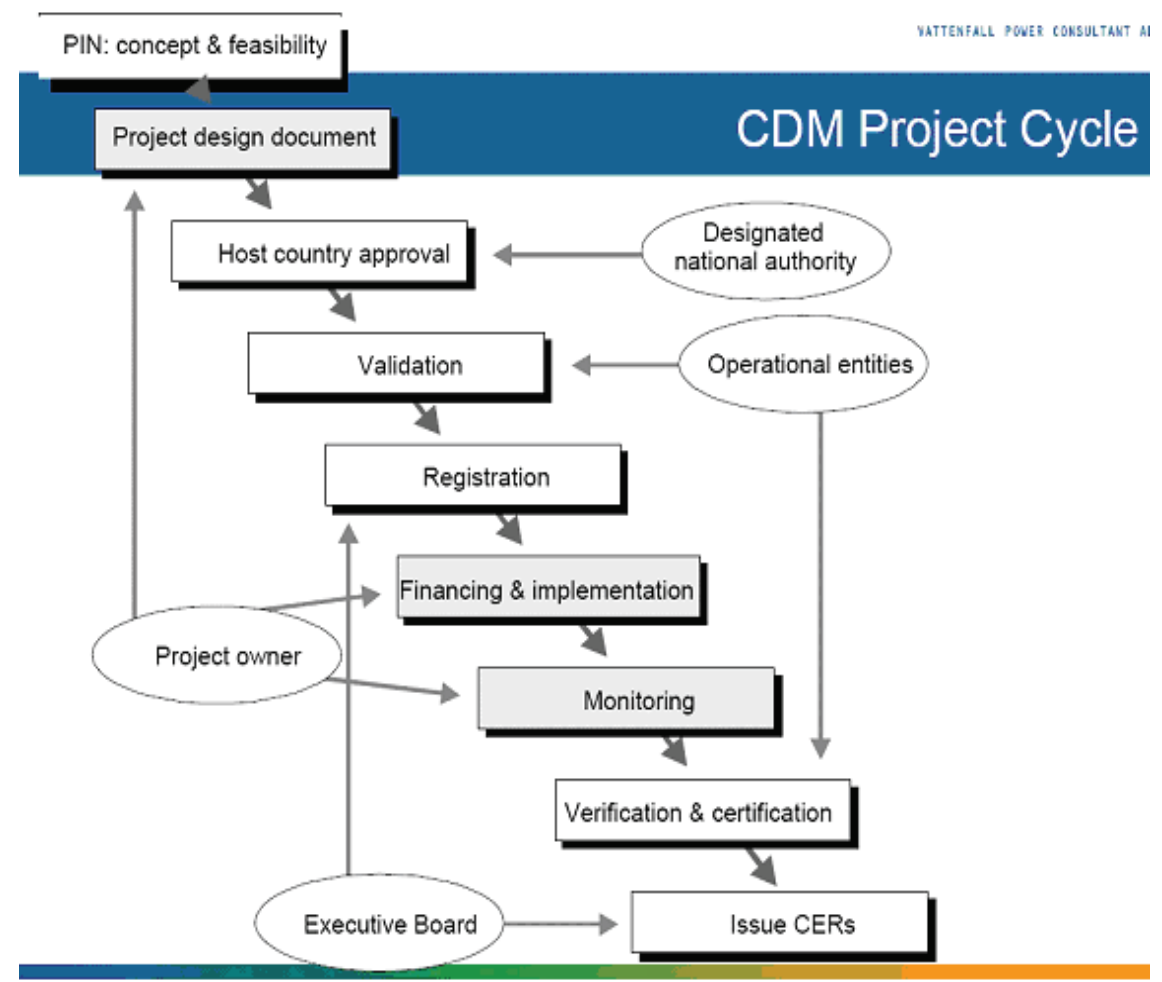

Figure 2. The CDM Development and Registration Process

\subsubsection{Current status CDM}

Total volume in the CDM market in 2009 was $211 \mathrm{Mt} \mathrm{CO}_{2}$, with a value of $\$ 2.678$ million, for 2008 the equivalent figures were $404 \mathrm{Mt} \mathrm{CO}_{2}$, with a value of $\$ 6.511$ million $^{9}$. By 1 November 2010, there were 2463 registered projects and 449,808,608 issued CERs ${ }^{10}$. The amount of CERs expected from registered projects until the end of 2012 is more than 1,840,000,000 ${ }^{11}$.

There are at present date about 4,200 CDM project activities under preparation, expected to deliver about 2.9 billion CERs. The issuance is currently one of the main bottlenecks in the CDM-procedure. In order to obtain the credits, the project results should be monitored and verified, which often takes longer time then expected due to work overload of audit companies and limited access to personnel qualified for such assignments.

In total, the expected time for a project in the decision cycle is 286 days for validation plus 153 days for registration and then 452 days before the

\footnotetext{
${ }^{9}$ State and Trends of the carbon market 2010, report from The world Bank

${ }^{10} \mathrm{http}: / / \mathrm{cdm}$. unfccc.int/index.html

${ }^{11}$ http://cdm.unfccc.int/Statistics/index.html
} 
first issuance ${ }^{12}$. This implies that any project owner would have to wait three years for any returns for CDM. Projects in least developed countries would benefit from carbon finance (i.e. CDM revenue) coming in earlier in the process, and improving the CDM process would imply creating a basis for seeing more CDM-projects in LDC.

The concept of additionality was introduced, meaning that the emission reductions are additional to any that would have occurred in the absence of the project. This is still an issue that the green movement brings forward and the current criticism is focused on large-scale hydropower projects in China and other parts of Asia, arguing that these projects would have been built regardless of the extra income of carbon finance that the CDM provides.

Another criticism of some types of CDM-projects is that they do not contribute to sustainable development, which is a relevant critizism in some cases where the project does not result in any benefit except reducing emissions. Reducing emissions by means of end pipe solutions in processing industries may have very little impact on the communities in the region. Other projects have significant positive impacts on sustainable development, for instance a biomass project where biomass boilers connected to the regional grid replace local diesel generators. Such a project can lead to improved local air quality, better profitability for the local industry (e.g. sugar, rice) and increased level of employment in the area.

\subsection{Joint Implementation}

\subsubsection{Introduction $J I$}

Joint Implementation follows the same principle as CDM except the fact that the JI host countries have quantified emission targets and carbon offsets are therefore taken from the host countries' allowances. The JI commodity is an ERU, Emission Reduction Unit (ERU), which equals one ton $\mathrm{CO}_{2}$ equivalent.

There are two "registration procedures" available for JI depending on the Kyoto Protocol institutional maturity of the country. With the Track 1 procedure, host countries can accredit auditors and manage the registration procedure themselves. However, this requires that the country has established a national system for emission inventory and reporting. Track 2 implies a process similar, but not identical to the CDM, overseen by the Joint Implementation Supervisory Committee.

\footnotetext{
${ }^{12}$ UNEP Riso Centre, CDM Pipeline Overview table 12 (Analysis), 2010
} 


\subsubsection{Current Status JI}

Total volume in the JI market in 2009 was $26 \mathrm{Mt} \mathrm{CO}_{2}$, with a value of $€ 252$ million ${ }^{13}$ By 1 November 2010, 191 projects under Track 1 and 23 projects under Track 2 have been submitted and published on the UNFCCC JI website $^{14}$.

The JI market was initially reduced by EU ETS double counting rules and is hampered by a short crediting period. Countries like Ukraine are also selling Assigned Amount Units, which can be used only for the Kyoto compliance of other governments. The income of the AAUs are earmarked for Green Investment Schemes, emission reduction activities in a particular sector of the country.

Project activities incorporating sustainable forest management and enhancement of carbon stocks are also eligible under JI, however limited to Afforestation and Reforestation ${ }^{15}$ as with the CDM.

The Joint Implementation has not yet demonstrated its full potential according to the expectations in the early 2000. This development is a result of several factors:

- The late ratification of the Protocol, leading to slow start up of project activities. JI projects could start earlier than 2008 but the crediting period starts in 2008. Some of the early start projects have been able to benefit from additional AAUs for the pre 2008 reductions.

- The entrance of Central and Eastern European countries into the European Union and the EU ETS leading to a reduced scope of JI in these countries. Given this development, much of the focus of JI has been oriented towards Russia and Ukraine.

- The short crediting period, limiting the incentive to initiate project activities.

- Uncertainty of the host country institutions' efficiency with regard to the approval process and the risk of non-issuance of ERUs.

When JI was launched with the Kyoto Protocol in 1997, the perspectives for investment in this mechanism were attractive. The implementation of mitigation projects in countries in transition was generally considered costeffective, perhaps more expensive than in developing countries, but less risky. However, in $2001 \mathrm{CDM}$ gained considerable competitive advantage due to the decision for operationalisation of the prompt start for CDM in the Marrakech Accords. This included establishment of the CDM Executive Board in 2001, while the JI Supervisory Committee (JISC) was established end 2006, and a much earlier starting date of CDM project crediting periods than in the case of JI: 1 January 2000 for CDM, compared to 1 January 2008

\footnotetext{
${ }^{13}$ State and Trends of the carbon market 2010, report from The world Bank

${ }^{14}$ http://ji.unfccc.int/JI_Projects/ProjectInfo.html

${ }^{15}$ Afforestation and reforestion are defined in 16/CMP.1, Annex, paragraph 1(b) and 1 (c)
} 
for JI. Until recently, JI has been lagging behind in terms of institutional arrangements and provisions for implementation compared to CDM.

Another reason for the slow start of JI was the crimping of the project supply as a consequence of the accession of 12 Central and Eastern European countries to the European Union in the period 2004-2007. The new EU Member States had to comply with EU policies and standards, including participation in the EU Emissions Trading Scheme launched in 2005 that covered the most CO2intensive sectors and installations. As result, the possibilities for JI in these countries have diminished dramatically and were limited to mainly small-scale and non-CO2 mitigation projects, except where the host country included a JI set aside in their National Allocation Plans.

When Russia's ratification saved the Kyoto Protocol in 2004, the interest for JI increased, but the delays in arranging the approval procedures for this potentially largest JI market has discouraged investments in JI. For a long time, the situation in Russia did not change with regard to the approval procedure, but finally in 2010, Russia has approved its first JI project.

Another drawback for JI is the increasing interest for International Emissions Trading and in particular for its variation Green Investment Schemes (GIS), elaborated in 2006, where host countries use part of the revenues of the AAU sales for investment in climate friendly infrastructure or programmes that will enable mitigation in the longer run. The opportunities provided by GIS and IET could make the allocation of AAUs to privatesector JI projects less attractive.

The mechanism is however far from marginal, countries such as France and Germany has approved several projects, including JI programmes of activities, under the first track scheme and as we will show below, also Nordic countries host JI projects.

\subsection{EU Policies and Regulations}

The EU has adopted several directives and goals aiming to regulate the use of JI and CDM credits in the EU ETS. The EU regulated the share of JI/CDM credits to enter the EU ETS by the so called linking directive. This directive, article 11a states that:

\footnotetext{
"Member states may allow operators to use CERs and ERUs from project activities...up to a percentage of the allocation of allowances to each installation, to be specified by each Member State in its national allocation plan for that period ${ }^{16}$.”
}

The directive also states that the use of mechanisms must be supplementary to domestic action. The limits for the use of CDM/JI credits vary between 0\% (Estonia) to 22\% (Germany) of allowances.

\footnotetext{
16 “Linking Directive”, 2004/101/EC
} 
In 2009, The EU adopted a wide-ranging package on climate change focusing on three areas: emission cuts, renewables and energy efficiency. The package introduced targets on all areas for 2020 compared to 1990 levels; a $20 \%$ increase in the share of renewables in the energy mix; a 20\% cut in energy consumption through energy efficiency; and a 20\% reduction in greenhouse gases. This latter target will rise to $30 \%$ if an international agreement is reached commiting other developing and developed countries to comparable emission reductions.

\subsubsection{EU Specific Rules for hydropower CDM projects}

Hydropower projects represent $24 \%$ of the number of CDM projects registered until October 2010 and 5\% of the expected CERs issued at 2012 of all CDM projects, 247 MCERs. However, installing large-schale hydropower dams can have significant environmental and social impacts and some dams can generate methane emissions due to anaerobic decomposition of submerged material. In order to limit EU-ETS access to projects that carry environmental and social risks, the European Commission has introduced restrictions on such projects. The "Projects" directive specifies that before endorsing a hydropower project with a capacity of more than $20 \mathrm{MW}$, Member States must ensure that relevant international criteria and guidelines, including those of the World Commission on Dams (WCD), are complied with.

\subsubsection{EU Commision opinion and suggestion on industrial gas CDM projects}

Some CERs are produced from CDM projects at refrigerant-producing factories that generate the powerful greenhouse gas HFC 23 as a by-product. These projects dominated the CDM's early growth, and are expected to generate $20 \%$ of all credited emission reductions by 2012 . The cost for destruction of hydrofluorocarbon 23 (HFC-23) can cost only $0.2-0.5 € / \mathrm{tCO}_{2}$ while it can generate CERs worth up to $12 € / \mathrm{tCO}_{2}$, depending on the country's tax policy and CER price at the time of ERPA signing.

The potential increase in production of HCFC-22 due to large profits through CDM provoked strong criticism. In an attempt to address concerns over HFC-23 projects, the CDM Executive Board made changes in how these projects are credited.

The European Commission has said it is concerned that credits related to industrial gases may be generating "windfall” profits from some developers and in November 2010 the Commission published a proposal that completely bans use of CDM credits from industrial gas projects as of 1 January 2013. The proposal reads:

\footnotetext{
"From 1 January 2013, the use of international credits from projects involving the destruction of trifluoromethane (HJC-23) and nitrous oxide (N2) from adipic acid production for the purpose of Article 11a of Directive 2003/87/EC is prohibited” (article 1).
} 


\subsubsection{Forest and plantation related activities in the CDM and in the EU ETS}

One of the major differences in policy for the EU ETS compared to the internationally agreed rules (i.e. the Kyoto Protocol) is that installations in the EU ETS cannot use CERs from afforestation or reforestation projects. The decision not to include CDM sink projects in the EU ETS was significantly affected by the fact that the UNFCCC rules for sinks in CDM not were agreed upon when the EU ETS Directive was adopted (The UNFCCC rules were adopted in Milan 2003). The decision was also a result of discussions within the EU. The divergent views within the EU are basically founded on two principal arguments. The proponents argue that it is internationally agreed to accept these projects and therefore should be included in the EU ETS, which is a system based on Kyoto Protocol principles. The skeptics argue that the integrity of the ETS would be harmed due to the fact that i) permanent emission reduction of these projects can be questioned, that ii) the price of CERs and ERUs would be significantly lowered, which will destroy the carbon market, that iii) the monitoring and reporting systems for LULUCF (land use, land use change and forestation) projects are not of sufficient quality, and iv) that Governments could end up being liable for sinks from which private companies received credits.

Allowing credits from REDD-activities is an issue that has been raised, but many EU governments have raised their concerns arguing that there is a risk of massive supply, which would reduce the CER price significantly and possibly destroy the market.

Concerning LULUCF as well as Reduced Emissions through Deforestation, REDD, The Commission, the Council and the European Parliament believe that global deforestation can be better addressed through other instruments, for example, using part of the proceeds from auctioning allowances in the EU ETS. In this respect the Commission has proposed to set up the Global Forest Carbon Mechanism that would be a performance-based system for financing reductions in deforestation levels in developing countries.

It is important to note that the EU ETS decision does not affect Member States right to use CDM A/R projects for Kyoto Protocol compliance. The ban on forestry projects only apply to installations covered by the EU ETS.

\subsection{4 "Domestic JI"}

There are two understandings of "domestic JI". One is what earlier was denoted as mailbox JI: a company with installations in two or more countries reduce emissions in one country and uses its sister company in the other country as buyer. 
The other notion stems from projects within a country or region outside the trading scheme. This is elaborated by the EU in the EU ETS Directive: Article 24a, Harmonized rules for projects that reduce emissions ${ }^{17}$ :

“...implementing measures for issuing allowances or credits in respect of projects administered by Member States that reduce greenhouse gas emissions not covered by the Community scheme may be adopted. Any such measures shall not result in the double-counting of emission reductions nor impede the undertaking of other policy measures to reduce emissions not covered by the Community scheme.”

Article 24 continues:

"Implementing measures that set out the details for crediting in respect of Community-level projects may be adopted..."

${ }^{17}$ Directive 2003/87/EC of the European Parliament and of the Council of 13 October 2003 establishing a scheme for greenhouse gas emission allowance trading within the Community and amending Council Directive 96/61/EC (Text with EEA relevance) 


\section{Nordic experiences}

\subsection{Nordic CER and ERU Purchasing Programs}

\subsubsection{Objectives of the programmes}

The Nordic governments have all participated in an early stage of the development of the carbon market, contributing to the creation of a functioning market for CERs and ERUs, partly by creating their own national JI and CDM programme, as the pilot programme in Finland 1999, the Swedish in 2002 and the Danish in 2003 are examples of. All Nordic governments have participated in World Bank funds as for example the Prototype Carbon Fund, which was the first launched carbon fund, and the Testing Ground Facility, TGF, managed by NEFCO. The governments of the Nordic countries have showed trust in the carbon market, which paved the way for private companies, consultancies and brokers to enter the market.

The Nordic governments have set the general purpose of their JI and CDM programmes differently - the Danish, Finnish and Norwegian programmes all have volume targets, while the Swedish does not. The Danish program is still purchasing for compliance, whereas the Swedish programme does not have a volume target and Finland's currently has no more budget allocations for further purchases. Norway is purchasing for compliance with domestic target beyond Kyoto.

Data on the national purchase programmes are gathered in figure 3 on the next page, and specific targets are further elaborated below:

Norway: The Norwegian Kyoto target is a 1\% emission increase. In 2008 Norway decided to over-fulfil the Khyoto target by $10 \%$. This, and various other decisions on the national level created a need to purchase an additional 6.6 million CERs or ERUs per year. The Norwegian government allocated funding for the CDM and JI programme with the objective of purchasing Kyoto units, while at the same time contributing to the development of the market and building experience.

Denmark: The Danish Kyoto target is a $21 \%$ emission reduction target and funds were allocated according to the "Cost Efficient Climate Strategy" adopted by parliament in 2003. The Danish JI/ CDM programme has a costeffective contribution to Denmark's Kyoto obligations, through acquisition of GHG reductions from JI/CDM projects. The Government is a compliance buyer and needs to supply 18,5 million credits for the period 2008-2012. In addition to the overall objective Danish JI/CDM programme has four strategic goals: 
- To contribute to global climate protection through sustainable climaterelated projects in Eastern Europe and developing countries

- To promote sustainable development in developing countries and Eastern Europe via transfer of technology and capital, social improvements and capacity building

- To compensate for $\mathrm{CO}_{2}$ emissions related to COP-15 and government travels

- To support Danish industry in the form of facilitating JI/CDM credit purchases by companies covered by the EU ETS, and to promote the export of Danish technology and know-how to JI/CDM projects.

Figure 3. Key figures of the national programmes ${ }^{18}$

\begin{tabular}{|c|c|c|c|c|}
\hline & Denmark & Finland & Norway & Sweden \\
\hline $\begin{array}{l}\text { KP reduction } \\
\text { target }\end{array}$ & $-21 \%$ & $0 \%$ & $+1 \%$ & $+4 \%$ \\
\hline $\begin{array}{l}\text { Voluntary } \\
\text { reduction target }\end{array}$ & - & - & $-9 \%$ & $-4 \%$ \\
\hline $\begin{array}{l}\text { Volume target } \\
\text { (M ton) }\end{array}$ & 18,5 & 11 & 40 & No \\
\hline $\begin{array}{l}\text { Money allocated } \\
\text { (M EUR) }\end{array}$ & 217 & 100 & 615 & 140 \\
\hline $\begin{array}{l}\text { Expected } \\
\text { deliveries (M } \\
\text { ton) }\end{array}$ & 22 & 11 & $\sim 40$ & $10-20$ \\
\hline $\begin{array}{l}\text { Post } 2012 \\
\text { purchases }\end{array}$ & $\begin{array}{l}\text { Smaller } \\
\text { amounts }\end{array}$ & Yes, $\sim 30 \%$ & Small volumes & $\begin{array}{l}\text { Yes, only full } \\
\text { crediting peri- } \\
\text { ods }\end{array}$ \\
\hline $\begin{array}{l}\text { Project type } \\
\text { exclusions }\end{array}$ & $\begin{array}{l}\text { HFC, Large } \\
\text { hydro, Forestry }\end{array}$ & $\begin{array}{l}\text { Large hydro, } \\
\text { Industrial gases }\end{array}$ & $\begin{array}{l}\text { Large hydro (>20 MW) } \\
\text { treated individually }\end{array}$ & $\begin{array}{l}\text { Large hydro, } \\
\text { Industrial gases }\end{array}$ \\
\hline $\begin{array}{l}\text { Purchase of } \\
\text { pCER/ERU }\end{array}$ & Yes & Yes & Only through funds & Yes \\
\hline $\begin{array}{l}\text { Purchase of } \\
\text { secCER/ERU }\end{array}$ & Yes & No & Yes & No \\
\hline
\end{tabular}

Finland: For the Kyoto period, Finland has commited to bring the national average annual emission down to their 1990 level. The volume target for the $\mathrm{JI}$ and CDM programme is $7 \mathrm{Mt} \mathrm{CO2.} \mathrm{The} \mathrm{main} \mathrm{motivation} \mathrm{is} \mathrm{to} \mathrm{purchase}$ cost-effective credits for compliance. The purchase programme also aims at providing for the post Kyoto carbon market period. In the end of year 2006, the Finnish government decided to make use of the possibility to claim removals by sinks according to Article 3.4 of the Kyoto Protocol and in June 2007 European Commission made its decision of the national allocation plan of Finland. These two decisions drastically reduced the need for additional CERs or ERUs. As a result of this, the Finnish CDM and JI programme funding was cut down and focus could also be aimed to post-Kyoto period.

Sweden: The Swedish Programme was not primarily created due to a need for credits for compliance purposes. The Swedish government ex-

\footnotetext{
${ }^{18}$ The Danish volume target 18.5 Mtonnes is exclusive of COP-15 and government travel compensation.

The money allocated for each programme includes different transaction costs and are not fully comparable between countries.

The 100 MEUR allocated to the Finnish programme includes 30 M EUR that are intended to be used for post 2012 credits.
} 
pected the Kyoto target, an increase of emissions by $4 \%$, to be met without use of the flexible mechanisms. Furthermore, the domestic ambition to reach $-4 \%$ did not include use of flexible mechanisms. The objective of the Swedish programme has since the outset been to contribute to the development of the market and to gain experience, to contribute to sustainable development in the host countries and to acquire cost-effective emission reductions. Accordingly, the Swedish programme has no volume target, which is unique among the Nordic countries. The current guidelines from Government is to distribute activities between bilateral projects and participation in multilateral carbon funds, to focus on high quality projects, to have a geographical spread of the projects and to make special effort to purchase projects in Least Developed Countries (LDCs) and Small Island Developing States (SIDS).

An important objective of the Swedish programme has been to use the experience of the programme as knowledge to be directly applied in the climate change negotiations, for instance by taking an active role in the mechanisms expert group under the WPIEI.

\subsubsection{Management of the programmes}

The management of the programmes have many similarities, but also some major differences due to the need of credits and the countries political support which are shaping the objectives of the programmes. The early stage programs in Finland, Sweden and Denmark, have identified projects at an early stage of development. These programs then developed projects inhouse or used contracted consultants. The Norwegian program started later. The programs have sourced projects with somewhat different approaches.

Denmark and to some extent Finland has since the outset made use of its embassies for cooperation, but also used existing networks in developing countries and the EIT (Economies in Transition). Norway has sourced projects directly from project owners, used intermediaries and carbon funds. Sweden, Denmark as well as Finland used open public tenders in the early days and Sweden has to a larger extent invested in multilateral funds, further elaborated in the next chapter.

\subsubsection{Participation in funds}

The Finnish, Swedish and Norwegian governments participated in the Prototype Carbon Fund, PCF, administered by the World Bank. The Danish government did not enter in the PCF, but invested in a specially created Danish Fund, also administered by the World Bank, called the Danish Carbon Fund (DCF). All Nordic governments participated in the Testing Ground Facility, the TGF, administered by the Nordic Environmental Finance Corporation, NEFCO, and Denmark has also invested in the NEFCO Carbon Fund. The Swedish government invested about USD 15 million in the Asia Pacific 
Carbon Fund, APCF, and USD 20 million in the Future Carbon Fund, both run by the Asian Development Bank, as well as EUR 2 million in the Multilateral Carbon Credit Fund, MCCF, administered by the European Bank of Reconstruction and Development, EBRD.

The Norwegian programme entered, in addition to the PCF and the TGF also in NEFCO Carbon Fund, described below in section 3.1.6.

In addition to PCF and TGF, where 10 million USD and 4,25 million EUR were invested respectively, the Finnish programme invested in two more funds for the Kyoto period: EUR 10 million in the Multilateral Carbon Credit Fund (MCCF) and USD 25 million in the Asia Pacific Carbon Fund (APCF).

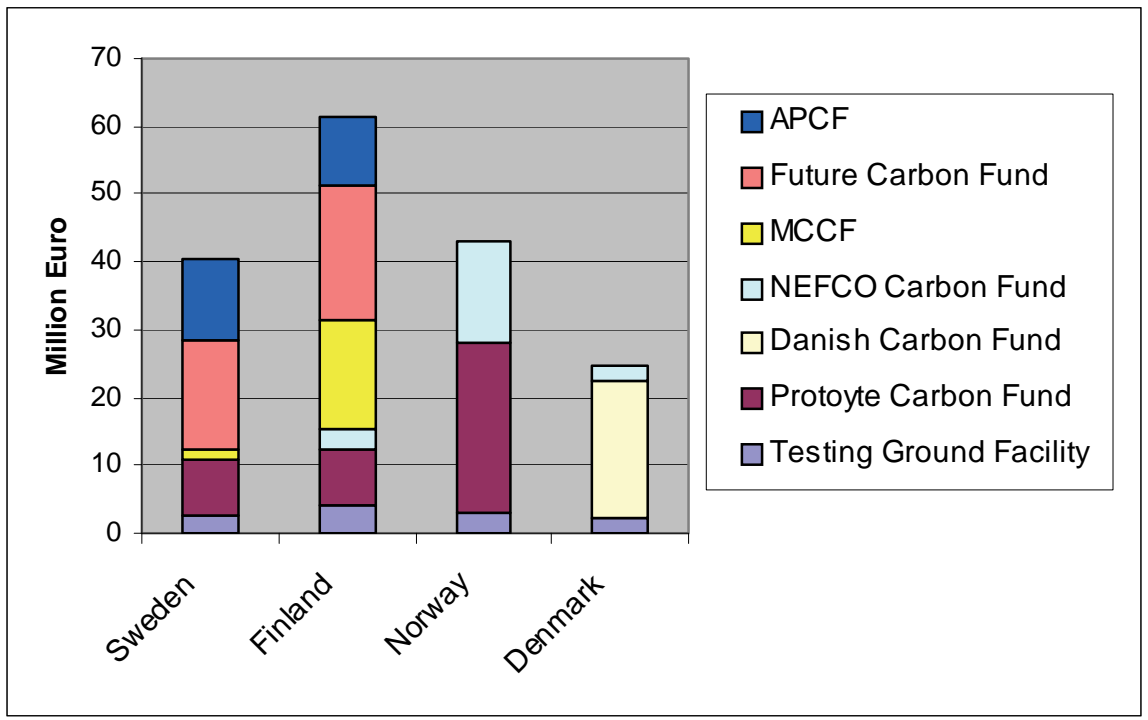

Figure 4. The countries involvement in multilateral funds.

\subsubsection{Stage of development of CDM and JI market}

A fundamental characteristic of the primary CDM and ERU market is that the more risk a buyer takes, the lower will the price be, and the less risk a buyer takes, the higher the price. For any buyer, the risk aversion is related to the need of certainty of delivery.

The Finnish and the Swedish programmes, as well as the Danish programme, were early players on the market, and built up their own organisation for the management and development of CDM projects. One of the objectives of these programmes was also to develop the carbon market and they have signed contracts with projects at an early stage of the CDM cycle.

The Norwegian programme signed contracts with quite a few projects at an early stage of the CDM cycle during the initial years of the purchase programme. In 2010, in order to reach the volume tarets and reduce the delivery uncertainty of its portefolio, the programme focused on more mature projects, and even guaranteed deliveries. The Danish programme will, for 2010 
and 2011, also focus on late stage projects bought over the counter (OTC) in order to fill their need for CERs before 2012.

\subsubsection{Criteria for purchasing}

All Nordic governments stress the importance of ensuring that the CERs or ERUs they purchase come from sustainable projects and all have criteria that they follow. Typical SD criteria are community development, improved air quality and introduction of renewable energy technology.

In some ways, the sustainability criteria differ between the Nordic countries:

The Danish CDM programme includes Corporate Social Responsibility criteria in the purchase contracts. The Danish programme has refrained from purchasing HFC and large hydro projects as well as non-specific secondary credits in order to ensure compliance with sustainability criteria for carbon credits.

The Finnish programme has stated that they will buy "only environmentally sound projects" which in their meaning means no HFC projects, no projects in palm oil plantations and no large scale hydropower projects (larger than $15 \mathrm{MW}$ ) in their bilateral CDM/JI portfolio.

Norway is in principle open to buy credits from all types of projects, which are or probably will be approved by the UN. Support for the UN system and the formation of a market based on a standardized product and a uniform price signal, is considered important.Risk analysis is made project by project. Hydropower projects above $20 \mathrm{MW}$ installed capacity will be treated individually, on the basis of the EU-ETS voluntary harmonization of the rules of the Linking Directive.

The Swedish government has formulated their criteria in directives from 2008 that stipulates that the programme should focus on "high quality projects that produce additional emission reductions”. The Swedish programme has most clearly expressed its interest in a geographical spread of the projects, and in particular that projects from Least Developed Countries (LDC) or Small Island Developing States (SIDS) should be included in the portfolio. The experience of the Swedish programme is that even with much effort and many project ideas in early stage, very few projects in LDCs in Africa are actually implemented. The problems of attracting underlying finance, overcoming institutional barriers in the host country as well as the barriers in the CDM rule system make the process extremely difficult.

\subsubsection{Nordic collaboration}

A large part of the Nordic collaboration in this area has been the joint efforts under the frame of the Nordic Environmental Finance Corporation, NEFCO. NEFCO is a multilateral financial institution founded in 1990 by Denmark, Finland, Sweden, Iceland and Norway to finance investments and projects 
that generate positive environmental effects in Russia, Ukraine, Estonia, Latvia, Lithuania and Belarus. NEFCO is also the fund manager for PublicPrivate Partnership procurement funds, focusing traditionally on the transitional economies but since 2008 also on developing countries. NEFCO manages two carbon funds: The Baltic Sea Region Testing Ground Facility (TGF) with a budget of EUR 35 million; and NEFCO Carbon Fund (NeCF) with a budget of EUR 100 million, in which governments participate. The NEFCO carbon funds focus their investments in energy efficiency and renewable energy projects.

\subsubsection{Purchase of Post 2010 carbon credits}

A major dilemma for the carbon market is the post 2012 uncertainty. Although almost every country is in support of CDM and a continuation of the carbon market, there is still no certainty with regard to the regulatory framework for CDM (and JI) after 2012, and particularly no certainty with regard to the demand.

The Norwegian programme has contracted a small volume of CERs to be delivered after 2012, but has until now not offered to purchase post 2012 CERs on a regular basis. The Danish programme acts in similar way, while the Swedish programme in general includes purchase during the entire first crediting period of the project, which might be 7 or 10 years. The Swedish, as well as the Finnish government, also participate in the Future Carbon Fund, administered by the Asian Development Bank, which specifically focuses on purchasing post 2012 CERs from projects in developing Asian countries. The Finnish government allocated especially EUR 30 million for post 2012 purposes. A part of that sum has been invested in the NEFCO Carbon Fund, and another part is allocated to cover the post 2012 share of payments from the Finnish CDM and JI programme.

\subsection{Public Finance and Nordic Institutions}

\subsubsection{The role of public finance}

A major concern for the international community dealing with climate change is how to create institutions and markets that provide for significantly increased flows of public and private sector financing to emission reduction projects. In particular, one of the key issues is how public finance can boost private sector financing.

Since the early stages of the development of the carbon market, government initiatives in the form of carbon credit purchasing programs and capacity building programs have played an important role for the establishment of a global carbon market. As is shown in Figure 5 below, private capital has been a significant share of the financing in the World Bank CDM projects. 


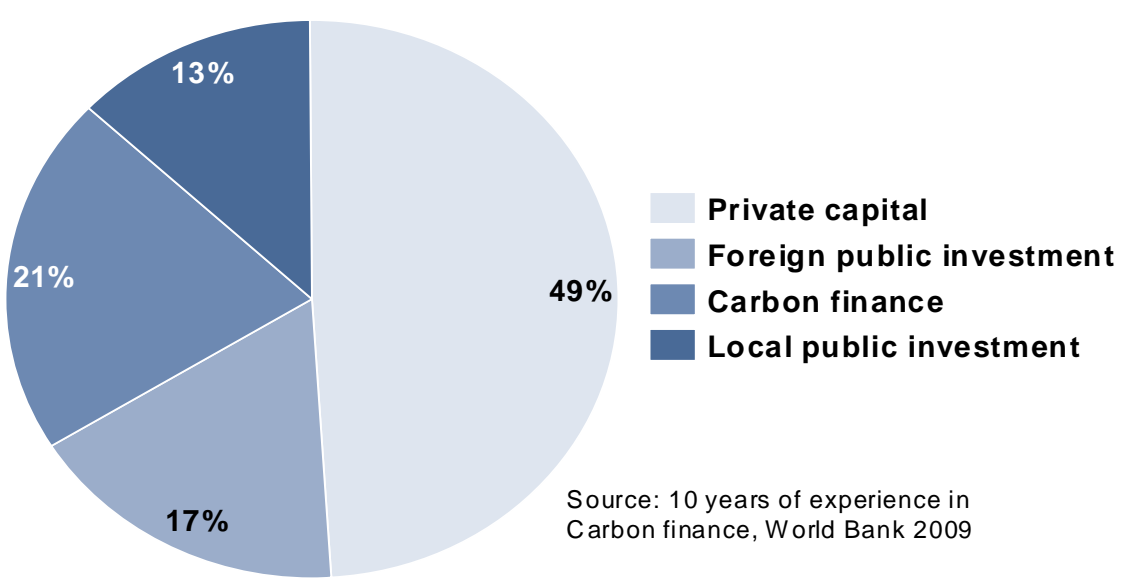

Figure 5. Origin of capital financing in World Bank CDM projects

However, to address the large need of low carbon projects in the developing countries, the role of public finance considers not only purchasing and providing capacity building, but arranging financing mechanisms that further spur investments in low carbon projects by the private sector, e.g. by providing guarantees.

There is substantial experience of public finance mechanisms that can be drawn upon when improving the market for emission reduction projects further. One is that it needs more public funding in the early stage of the technology development cycle ${ }^{19}$. Other important factors for enhanced climate mitigation actions are ${ }^{20}$ :

- Increased level of available capital to cover incremental costs associated with low carbon investment;

- Strengthened institutional capacity of governments to develop and implement public policies to reduce carbon related risks for private investors;

- Creation of technical capacity for enabling transfer of technology and related know-how.

The need for public finance support to overcome market barriers at early (and later) project development stages and the particular public finance mechanisms that can address this problem is of particular concern and was also one of the main issues raised during the workshop 2 .

\footnotetext{
${ }^{19}$ UNFCCC (2009) Investment and Financial Flows to Address Climate Change: An Update

${ }^{20}$ Amin, Amal-Lee (2009) Carbon Finance: Driving Technological Transformation of the Global Economy in IETA Carbon Market 2008
} 


\subsubsection{Government Risk Mitigation Measures Related to the Carbon Market}

Governments can apply a number of policies and measures in order to promote low carbon projects. One necessary condition is that there are overall economic framework conditions for investments in low carbon projects. Another necessary condition is that there is a set of instruments that can remove barriers. Among these instruments are investment grants, interest rate subsidies, dedicated credit lines, investments in private equity or venture capital funds, and publicly backed guarantees ${ }^{21}$.

Investment subsidies, grants or interest rate subsidies increase the financial rate of return of an investment which increases the incentive for an investor and can also increase the investor's access to debt finance.

Funds are established with the purpose of injecting public finance into the commercial system, in particular in markets where there is a lack of liquidity and where the private financers prioritize other investments.

Publicly Backed Guarantees and insurance schemes mitigate risk and thereby steer the flow of private funds towards prioritized areas. These mechanisms provide beneficiaries with access to finance, reduce their cost of capital, and can expand loan tenor or grace periods to match project cash flows. PBGs are very useful in the context of promoting emerging or higher risk technologies. PBGs are of particular importance to CDM since they can address barriers that are typical for project finance. For instance, there are in many cases high-risk premiums on loans to renewable energy and energy efficiency projects where "demonstration level” technology is applied.

Multilateral Development Banks can act as providers of public finance in the form of loans, grants and guarantees for energy infrastructure investment within developing countries. MDBs can provide loan guarantees ${ }^{22}$, can also offer risk-sharing mechanisms, and provide equity investments used to establish revolving funds to mobilize public and private sector funds.

The World Bank has had the view that public finance, including ODA, can fill financing gaps together with carbon finance, where carbon finance would ideally be used and exhausted first before the public funds/ODA is used. This principle is for instance codified in the Clean Technology Fund, also administered by the World Bank as part of the group of funds called the Climate Investment Funds. The Clean Technology Fund contribution to a project is meant to basically cover some of the incremental cost of cleaner technology. Several multilateral organizations and funds, such as the Asian Development Bank, and UNEP, stress that risk sharing is of outmost importance to create better leverage of investments.

A main element in the proposals of these organizations is that government high risk capital in funds could take the losses from early failed projects. UNEP argues that institutional investors could provide much of the capital, if an appropriate risk-reward balance is offered. Institutional investors, such as

\footnotetext{
${ }^{21}$ SEF Alliance (2010) Publicly Backed Guarantees as Policy Instruments to Promote Clean Energy

${ }^{22}$ Amin, Amal-Lee (2009) Carbon Finance: Driving Technological Transformation of the Global Economy in IETA Carbon Market 2008
} 
pension funds, insurance companies and sovereign wealth funds, are in a position to provide some of the required capital. It is estimated that pension funds alone control assets worth more than $\$ 12$ trillion and that sovereign wealth funds have a further $\$ 3.75$ trillion under management. However, to stimulate their engagement the expected returns on climate-change mitigation investment need to be commensurate with the perceived level of risk. Several risks need to be managed, including country risk, policy risk and currency risks. Public financing that covers country and currency risk and cushion other generic risks reduce the absolute return required by institutional investors and increase the supply of private finance for emission reductions. Some publicly funded bodies undertake early-stage project execution for infrastructure projects, such as securing consents and off-take arrangements. In the Nordic context, in which the purchasing programs prioritize renewable energy, public finance could play a role in such projects.

\subsubsection{Nordic public finance institutions}

Looking at the Nordic arena, there are organizations established since many years in the Nordic countries that carry out the tasks above. Development agencies contribute to improving the overall political and economical framework in developing countries in order to create conditions for economic growth and to alleviate poverty. The organizations are in this case DANIDA, SIDA, NORAD and FINIDA.

There are also organizations aiming at injecting public finance into projects that are implemented in developing countries where the conditions for investment are difficult. These organizations are denoted Development Finance Institutes, and in the Nordic countries these are Finfund, IFU, Norfund, Swedfund.

Finally, the Nordic countries have also established guarantee institutions that provide risk sharing. These organizations are EKF, EKN, GIEK and Finnvera. On the Nordic level, there is the Nordic Investment Bank (NIB), NEFCO and the Nordic Development Fund (NDF).

\subsubsection{Summary of views}

In sum, the discussions during workshop 2 pointed out:

- $\mathrm{CDM}$ is not designed to solve all financing barriers to projects. Even though CDM has a positive contribution to the overall economic performance of projects, it does not, or only to a limited extent, solve barriers related to the underlying financing of projects. Initial investment costs are covered by equity and debt as in any project not involveing carbon finance. It is possible to argue that this is the way it should be, since buyers e.g. do not pay in advance for the electricity produced from a renewable energy project. One of the predicaments is however 
that the ERPA, due to the risk of registration and issuance delays or failures, may not have the same value, e.g. as collateral security, as the Power Purchase Agreement for electricity.

- Early development funding has not increased significantly with the CDM and it seems as if there is room for a larger role for public finance to play at this stage. Funding that can reduce risk is very much welcome, e.g. by providing guarantees.

- The value of CDM or JI, i.e. the value of an ERPA varies between actors. In a system where carbon finance income would be more predictable and the part of the income would be larger, the significance of an ERPA would be higher. The value of an ERPA seems to range from marginal to something that is important as part of the whole financing picture.

- Public finance could do more to increase demand and to contribute to a higher price levels that would give a stronger signal to make the investments.

- Risks could be better analyzed and presented in order for different actors to make a sound judgment of their own risk taking. It is e.g. often the case that the CDM registration risk is given a lot of attention whereas other real risks are with the creditworthiness of the project owner and the stability of the host country.

- Public finance can play an important role in improving the JI/CDM mechanisms, making the markets more effective, and breaking new ground for the CDM in Least Developed Countries as well as in developing the market for new up-scaled mechanisms.

\subsection{Lessons learned on the CDM and JI}

The Nordic countries have been involved in the development of several early stage projects related to the carbon market. On the positive side, the programmes have contributed to cost-effective implementation of national climate strategies, to technology transfer, and to capacity building and sustainable development in host countries. These positive results are a result of good collaboration, the ability to overcome bottlenecks and a good reputation in the market. However, the projects have also shown challenges and issues related to these projects. In this chapter the lessons learnt are described through the awareness of barriers and possible actions to overcome these barriers. The figure below describes the type of lessons learned that are further elaborated below. 


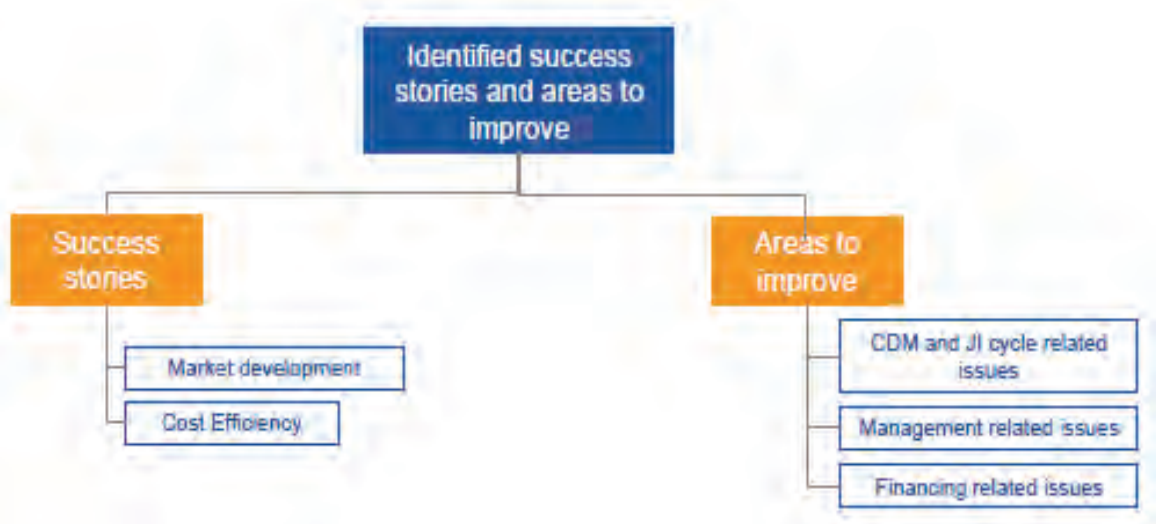

Figure 6. Summary of identified success stories and areas to improve for CDM and JI projects

The experiences from the Nordic countries (including NEFCO) consist of all possible issues related to the JI/CDM project cycle, notably delays in validation/registration and verification/issuance. The experience also includes the difficulty of contributing to the implementation of small-scale projects. To overcome barriers related to the registration process and to safeguard expected issued volumes, it is generally recognised that the CDM and JI programme must allocate resources related to registration and issuance: The project owners must often be assisted until first issuance. In addition, it has proven wise to keep good relations at high level with the DOE in order to ascertain that the validations and verifications can be done within reasonable time frames. Early and repeated communication with the host country DNA is also useful in order to have Letter of Approvals in due time. In order to check issues related to

Corporate Social Responsibility and the issuance and implementation of the projects, regulatory visits to the project and their project owners are recommended.

The lessons learned suggest that it is useful to form a network with organizations such as embassies, governmental investment funds, CDM/JI developers, host country DNAs, other buyers, brokers, financial institutions and DOEs. An established network and good reputation is crucial in order to identify and to manage follow up of projects. NEFCO's relative success in the Baltic countries was e.g. due to long standing presence and reputation in the market.

The programs have to a larger or lesser extent based their purchase on inhouse capacity. A few of the countries have experienced that one of the problems of running a programme inside a ministry or a government agency is that the mobility of staff is quite high. Governmental CDM and JI programmes sometimes act as "schools" for desk officers, who learn the business and move to private purchasers after a few years. Even if this can been seen as the governmental programmes contribution to the development of the Carbon market, lack of experienced personnel may cause problems for the programmes.

Another disadvantage of running a government purchase programme with dependence on in-house capacity could be the time from project identi- 
fication to the decision to make a bid. If not adjusted to the CDM market, semi-political or bureaucratic decision-making may not be able to provide for the quick responses that may be needed in order to get a deal with a project owner. This is a challenge that may be resolved by measures such as clear mandates to the responsible organisation and to the operational unit of the organisation. Experience from the Nordic countries shows that government programmes can apply an efficient decision procedure and even be faster than private companies.

The experience shows that purchasing through funds can be a good way of managing a portfolio if the national agency or ministry has limited personnel working with the CDM and JI programme, assuming that the sum invested in the fund is of substantial size.

All programs have faced barriers with regard to the underlying financing of projects, e.g. it has been challenging to use the Emission Reduction Purchase Agreement as collateral for loans or get bank guarantees for advance payments and it has been difficult for projects in Least Developed Countries to achieve financial close for the underlying project. Furthermore, in many cases there is a clear need for upfront financing in renewable energy projects, since these projects often require a large investment in advance of cash flow from energy/electricity generation and CER delivery. . Herein lies a potential role for public financing mechanism, which offers the guarantees, based on the ERPA contract as a security instrument.

There are, however, developments that the programmes could not influence. Firstly, the programs, although using public funding, do not regularly solve issues related to the financing of the underlying project. Project financing, for instance advance payments is problematic where capital markets are not well developed and security issues for these prepayments need to be addressed since carbon procurement vehicles such as the TGF are unable or unwilling to take significant credit risks. Herein lies a potential role for a public financing mechanism, which offer guarantees based on the ERPA contract as a security instrument.

Secondly, due to the balance between the size of the programs and the potential supply of CDM projects in the post 2012 market the programs may to some extent contribute to the enhancement of the post 2012 market. Some programs have, however, created a demand for post 2012 CERs to the extent possible given the budget of their programs, by presenting firm offers on post 2012 CERs, investing in post 2012 multilateral funds, private funds as well as co-operating with other government programs.

Thirdly, the situation in Russia has also developed in a way that was not conceived by the Nordic programs. There have been sincere attempts to boost JI through the Baltic Sea collaboration and dialogues with Russia but only in the spring of 2010 is there a functioning JI approval procedure in Russia and only as end of summer 2010 the first projects received Russian Letter of Approval. This could be an important lesson when the Nordic countries plan collaboration with countries or regions to test sectoral mecha- 
nisms, but there is also a strong case for continuing JI in Russia, Ukraine and other EITs as so much effort has been spent to build up procedures that are now in place with only a few years to go before 2012 and the reduction potential remains large. 



\section{Mechanisms in the future}

\subsection{Improving CDM Approval Process}

All projects that aim to generate CERs under the CDM rules must meet essentially the same criteria and complete the same steps, a process commonly known as the CDM project cycle. An initial step in the project cycle requires that project proponents undertake a lengthy eligibility exercise, including the justification of project additionality and identification of the baseline scenario, which is the level of emissions that would have occurred were it not for the CDM project. Streamlining and simplifying this process through the introduction of standardization methods could decrease project costs and increases access to the CDM.

According to the the CDM Modalities and Procedures, the Conference of the Parties serving as the meeting of the Parties of the Kyoto Protocol (COP/MOP) shall have authority over and provide guidance to the CDM Executive Board (EB) while the EB shall supervise the CDM and be accountable to the COP/MOP. The reform of the CDM could be classified into reform before 2012 and reform after 2012. Before 2012, the reform should happen within the framework of the CDM Modalities and Procedures as established in the Marrakesh Accords; while for the reform after 2012, such restrictions do not exist and more radical improvement could be introduced. The COP/MOP has given guidance to the EB to improve and reform the $\mathrm{CDM}$, covering various aspects. The COP/MOP has also requested the Subsidiary Body for Scientific and Technological Advice to recommend modalities and procedures for the development of standardized baselines.

\subsubsection{Standardized baselines}

Currently, the baseline for CDM projects is determined on a project-byproject basis. In the international negotiations, it was proposed that standardized baselines should be used on a national or sub-national level for specific project types. Standardized baselines both address CDM in its current form and the sectoral approach and are on the agenda of the Subsidiary Body for Scientific and Technological Advice following the request from COP/MOP.

The main idea of standardized baselines is step away from subjective decision-making, reduce transaction costs and simplify rules of the CDM. Standardization refers to the adoption of generally accepted uniform procedures, and is used to enable objective comparison or judgment to simplify and add more predictability to decision-making. In particular, standardization could increase: 
- the objectivity of additionality demonstration;

- objectivity and simplicity of baseline selection;

- simplicity of emission calculations and monitoring.

The basic idea of standardized baselines is that a project's emissions are compared to that of peers. Emission reductions below a standard levelwould then receive credits. In the CDM, there can be standardized methods for:

- the establishment of additionality;

- the determination of baseline emissions of the project or program (i.e. the crediting baseline);

- the determination of actual project or program emissions after the project has been implemented in order to be able to request credit issuance.

The concept of simplifying the procedure in a standardized approach is not new to the CDM; it is simply underused. For example, several examples of emission intensity benchmarks (often called grid emission factors) can be found in approved methodologies such as ACM 0013 and ACM 0002.

Four new types of standards have been discussed:

1. Positive list, aimed to streamline the process of establishing what can be credited. A "positive list” could contain certain project types in certain regions, which would, if they were to go through a full additionality test, in all likelihood prove to be additional, but where the transaction cost connected with conducting a full additionality test is prohibitive to project implementation.

2. Emissions or "performance" benchmarks

2.1. Set baseline emissions and establish additionality for project and program activities for which the business-as-usual GHG intensity per unit of production can be established. Examples of project types that could use this type of benchmark include: cement production, aluminum production, nitric acid production, appliance efficiency, and vehicle emissions intensity.

2.2. Set baseline emissions levels in combination with a standardized additionality test based on a binary benchmark. Examples of project types that could use this type of benchmark include: power plants based on renewable fuel. The development and use of emissions intensity benchmarks has proven particularly difficult because of a lack of the data available to individual project developers. A designated work program to gather such data at a level higher than individual project developers would substantially ease these constraints. 


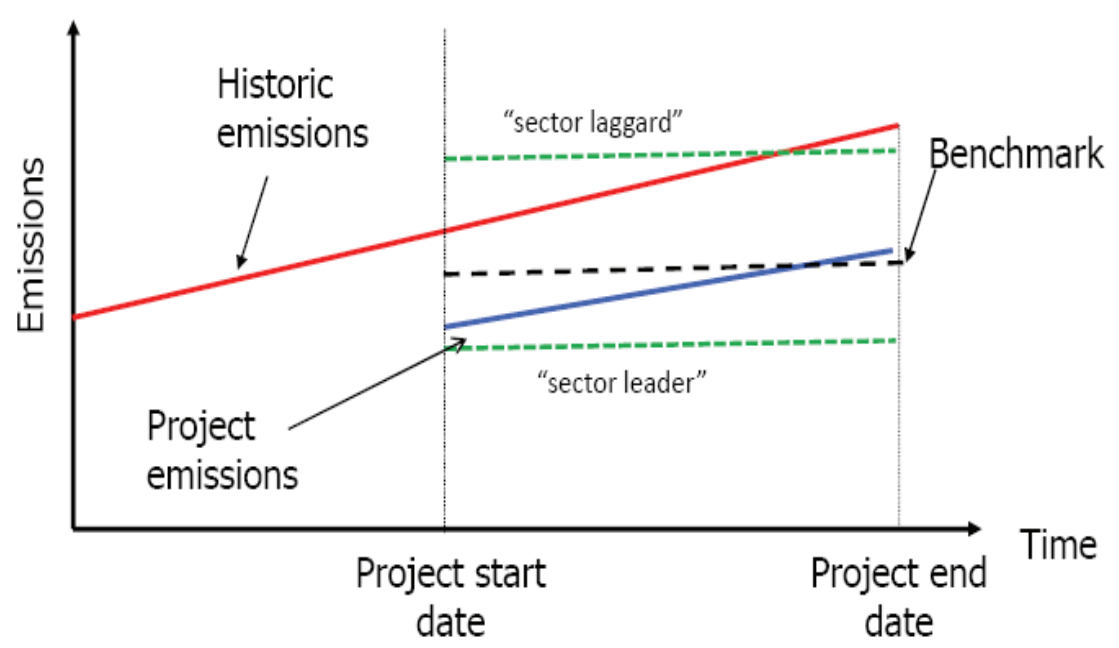

Figure 7. Emmission or "Performance” benchmarks. Source: Eco Securities

3. Technology benchmarks or "baseline penetration"

3.1. Deemed or Per Unit Values help determine the emission reductions of a project or program activity by allowing project participants to multiply a conservative estimate of the average emission savings of a given unit by the number of those units involved in the project activity, rather than carry out an extensive and costly monitoring plan. Examples of project types that could use deemed values include: solar lamps, high efficiency cook stoves, and high efficiency light bulbs.

3.2. The use of default factors or deemed value approaches will reduce the development costs even more than positive list or use of benchmark, thereby further increasing the commercial viability of currently unprofitable projects.

4. Default factors

4.1. Default factors help streamline the process of gathering the necessary data for the determination of emission reductions by using conservative default values in place of actual measurements. Default values are normally based on actual existing measurement data of similar, but not identical, conditions and are already used in many methodology types, particularly in countries where data is unavailable and/or costly to obtain. For example, ACM 0010 for manure management systems rely on many default values from the IPCC's 2006 Guidelines for National Greenhouse Gas Inventories in place for actual measurements for animal weight, biological oxygen demand, volatile solids, etc.

4.2. Default factors may in some cases be used for several small countries that share a grid system as well as social and economic characteristics, e.g. small countries in Africa. Similarly, a 
common benchmark and default factors may prove very helpful in facilitating several types of programs of activities, in particular those distributing compact fluorescent light bulbs. In other cases, in very large countries, it may be necessary to have several benchmarks within the country to address significant differences between different areas.

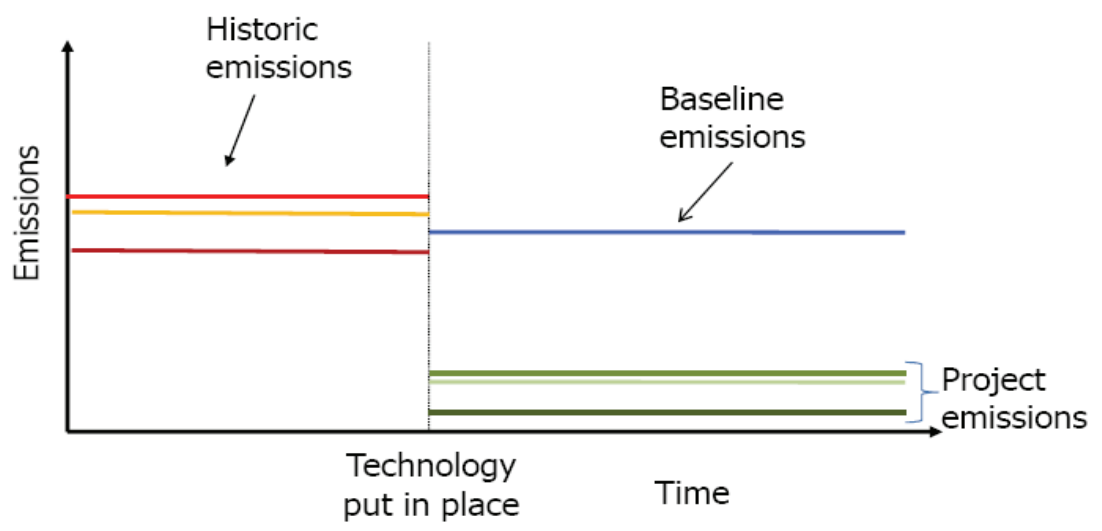

Figure 1. Default factor. Source: Eco Securities.

\subsection{Financing}

The negotiations taking place under the Ad Hoc Working Group on Further Commitments for Annex I Parties under the Kyoto Protocol (AWG-KP) have considered improvements and changes of the existing mechanisms. However, not all barriers are due to the existing rule system and the remedy could partly be found in public financing.

\subsubsection{Publicly Backed Guarantees - introduction}

When the flexible mechanisms were launched, a common anticipation was that the model for identification and developing of JI and CDM projects would be a government or company ingmake an investment in another country and that the investment would result in carbon credits to be used for compliance. However, the model has rather become that the project financing has been arranged unilaterally and that the CDM or JI investment is limited to payment on delivery, thus not entering among the finance provided at the early stages of the project.

A few companies combine CDM with equity investment, but the general model is that carbon finance partly covers annual operating costs (including loan down payments) and provides for an improved cash flow, thus contributing to the financial close of the project in the same way as any other revenue.

For many compliance buyers and government purchase programs, investing in the underlying project is not part of the entity's core business. Upfront 
payments of CERs or ERUs may partly address the lack of equity problem. However, given the risk related to the registration process and the performance of the project, many buyers are unwilling to make upfront payments, and those who do, require a significant discount on the CER price. In addition, most buyers require a bank guarantee when offering upfront payments, which also comes with a cost that will be taken by either the buyer or seller according to contract, and that cost will imply additional discount on the price.

An important instrument for addressing particular needs in sectors and countries are the publicly backed guarantees (PBG). These mechanisms provide beneficiaries with access to finance, reduce their cost of capital, and can expand loan tenor or grace periods to match project cash flows. PBGs are very useful in the context of promoting emerging or higher risk technologies. PBGs are financed by governments but typically recover costs of losses with fees.

The export credit guarantee organizations listed in chapter 3.2.3 are examples of risk sharing organizations and provide services within the concept of publicly backed guarantees. The export credit guarantees could be classified under technology transfer guarantees. PBGs can be designed in many ways in order to suite particular needs and situations.

PBGs are of particular importance to CDM since they can address barriers that are typical for project finance. For instance, there are in many cases high-risk premiums on loans to renewable energy and energy efficiency projects where "demonstration level” technology is applied. PBGs can also be used when addressing project finance for example, for small-scale grid connected renewable projects. In the latter case, the guarantees can improve the incentive of a financial institution to enter, and it can assist in securing sufficient equity finance.

\subsubsection{Pro Climate Facility}

One solution to solve the specific difficulties related to upfront payment or loans could be to introduce guarantee facilities such as the ProClimate Facility. In the autumn of 2009, NEFCO proposed to establish a climate guarantee facility to support targeted small and medium investments in renewable energy, waste management and energy efficiency projects or programs of activity that reduce greenhouse gas emissions and are eligible for carbon financing through CDM. NEFCO proposed that the facility should target a specific region, e.g. the Mekong Sub-Region (Cambodia, Lao PDR, and Vietnam) and Sub-Saharan Africa, with a possibility to later expand operations to other Nordic partner countries. The concept was later presented to the Nordic Development Fund. 
In June 2010, the Nordic Development Fund's Board of Directors approved financing of EUR 10 million for the ProClimate Facility (ProCF) ${ }^{23}$. The facility is intended as a general climate guarantee instrument and will be implemented jointly with NEFCO.

The facility could be used when a company developing an energy or waste project (the borrower) could not acquire a necessary loan from a local or regional financial institution without a partial loan guarantee granted by a creditworthy third party. The Facility could then reduce collateral and equity requirement significantly by providing to (i) the procurement fund or (ii) a local or regional financing institution, a partial loan guarantee to cover the advance payment (loan) component of an ERPA contract to increase the debt financing of the projects.

The Facility can extend partial loan guarantees, technical and operational guarantees as well as technical assistance to selected projects. As an innovative element the facility can enable different kinds of advance payments on deliveries and supplies, such as Certified Emission Reductions (CERs) in CDM projects. Attaching technical assistance to the selected projects is expected to further enhance the efficiency of the facility.

NEFCO participated in an innovative landmark post 2012 transaction in 2010, which used an offtake agreement, jointly with the KfW Development Bank. The agreement included loan disbursement using the ERPA as collateral, which monetized payment for grid connection costs for two large Mexican wind power projects ${ }^{24}$. However, these deals are all too uncommon in the carbon market, where conventional security instruments are usually demanded, if advance payments are offered at all.

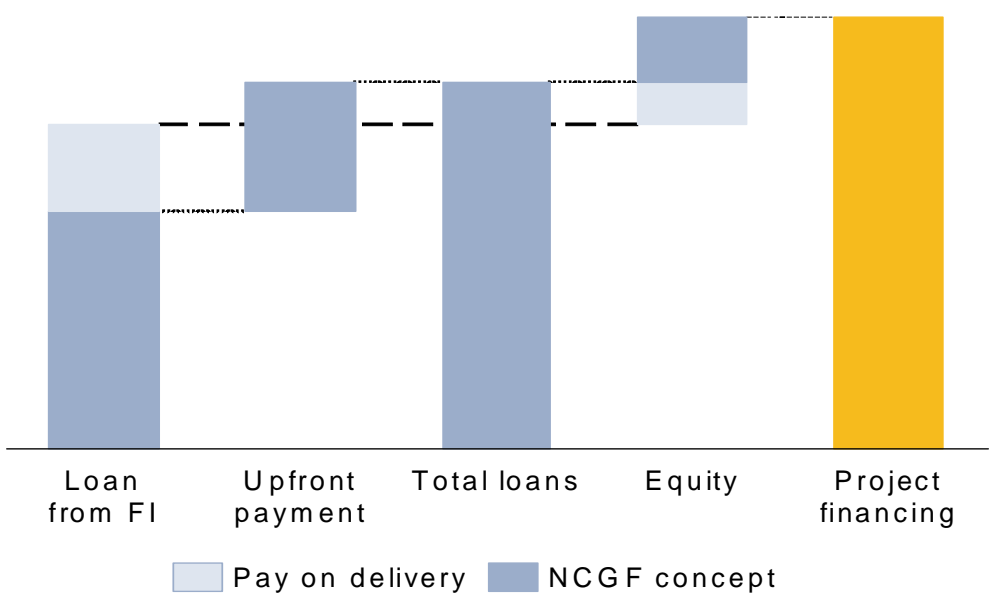

Figure 9. Reducing Loan and Equity with Advance CER Payments

\footnotetext{
${ }^{23}$ It should be noted that at the time of writing, the modalities and procedures of the Pro-Climate Facility have not been agreed. Hence, this section refers to the proposal by NEFCO rather than to imply any proposed undertakings by the Pro-Climate Facility.

${ }^{24}$ The transaction, one of the largest announced so far -4.6 million CERs, takes the form of a carbon collateralization structure based on the CERs purchased by KfW and NEFCO. Under this structure, the future receivables derived from the Emission Reductions Purchase Agreement fronted by KfW will rely upon by the principl lender, Banco Santander as the main source of repayment.
} 


\subsubsection{Climate Bonds ${ }^{25}$}

During the last couple of years, the World Bank and other organisations have worked with green bonds and in 2009, several institutions and banks have picked up on the idea to elaborate green sectoral bonds or climate bonds. Some of the proposals that have been communicated also contain carbon credits as part of the income stream from the bond issuer. A climate bond is issued by a government or corporate entity in order to raise finance for climate change mitigation projects or programs.

Like normal bonds, the issuing entity guarantees to repay the over a certain period of time, plus either a fixed or variable rate of return. The difference is that climate bonds are ringfenced with investors being promised that all funds raised will only go to climate-related programs or assets, such as renewable energy plants or climate mitigation focused programs. Compared to green bonds, climate bonds are specifically directed towards mitigation or adaption, where as green bonds address environmental projects or programmes generally.

A bond is a debt security, in which the authorized issuer owes the holders a debt and, depending on the terms of the bond, is obliged to pay interest (the coupon) and/or to repay the principal at a later date, termed maturity. A bond is a formal contract to repay borrowed money with interest at fixed intervals. Thus a bond is like a loan: the issuer is the borrower (debtor), the holder is the lender (creditor), and the coupon is the interest. Bonds provide the borrower with external funds to finance long-term investments. Bonds must be repaid at fixed intervals over a period of time.

Climate Bonds are an opportunity to invest in climate solutions through a high quality credit fixed income product and they are a result of the need to produce investment products that appeal to large investors. The first green bond structures did not explicitly work with carbon credits, but proposals incorporating carbon credits are currently being tabled.

The IETA has proposed a scheme for climate sector bonds suggesting that these should be issued with the approval of an international body, which would administer the mechanism. IETA suggests that the international oversight body would apply benchmark standards to the bond, which should remain unchanged for a certain period of time, after which they could be reviewed. Host countries would then issue the bonds with credit support by one or more international financial institutions. IETA further suggests that the bonds would be issued with a low-coupon rate and a stream of carbon credits to be split between the investor and the project sponsor. The bonds are suggested to be fully tradable.

In IETAs proposal, if emissions reduction targets are not met, the bond issuer would have to pay a cash equivalent to holders. If a sector covered by the bond failed to deliver agreed emissions cuts, carbon credits would not be issued to bondholders. If reductions failed to happen for a pre-defined num-

\footnotetext{
${ }^{25}$ This section is based on a VPC study for the Swedish Energy Agency and the IETA proposal for Climate Bonds
} 
ber of subsequent years, the bond issuer or host country would have to make an early payback of the bond.

In a similar vein, JPMorgan, an investment bank, has introduced the concept of a green sectoral bond scheme. A basic principle of this approach is that interest normally paid for the securities is replaced with the guarantee to physically deliver a pre-defined number of CERs/ERUs per debt security. According to JPMorgan, green sectoral bonds provide up-front financing with the following benefits:

- They allow the issuers to develop CER/ERU projects with up-front financing received;

- They align the investors explicit credit risk to the sovereign entity with the country risk implicit to primary project investing;

- The buyer of CERs/ERUs takes less risk, compared to primary project off-take agreements;

- The structure also provides several layers of protection for the buyers in the event that the project fails to deliver.

JP Morgan suggests that a guarantee is provided by a sovereign or supranational entity to provide credit enhancement. The delivery of the credits is structured as a physically or financially settled CER/ERU security each with defined maturity dates. The credit security can be either structured to be either principally protected (guaranteed by the issuer) or more exposed to CER/ERU market risk ${ }^{26}$.

The climate bond idea is quite recently launched and how it could work together with CDM programme of activities or a new NAMA/sectoral crediting mechanism is not yet fully explored. The verification of emission reductions and issuance of carbon credits is one way of securing and showing that the funding raised through the bonds results in actual emission reductions.

\subsection{Sectoral or NAMA crediting}

\subsubsection{Definitions}

Sectoral approaches, i.e. sectoral agreements and intra sector arrangements have been launched as a way of addressing emissions in developing countries with the aim of (i) addressing competitive distortion; (ii) getting developing countries more involved in mitigation actions and; (iii) creating an upscaled alternative to CDM. Sectoral approaches or actions are general terms covering all concepts, which include elements at a sectoral scale (e.g. electricity production, steel, cement etc). They are important since the climate change challenge is such that project specific actions are unlikely to be suf-

\footnotetext{
${ }^{26}$ Based on a presentation by JP Morgan
} 
ficient to leverage the investments needed for adaptation and mitigation in developing countries.

Other drivers are that politicians want to address sectors that are (i) not well suited for domestic policies and measures due to the international character of the sector, such as international transport (ii) not expected to be dealt with domestically within developing countries to a satisfactory level due to lack of financing and lack of international pressure (i.e. no quantitative legally binding domestic GHG reduction target).

Sectoral mechanisms, sectoral crediting or NAMA crediting are something more specifically oriented towards crediting and trading. Sectoral or NAMA (National Appropriate Mitigation Actions) crediting is based on a model where verified reductions of emissions below a defined level are credited for an entire sector. Credits are issued ex post, in a way similar to CDM, i.e., no credits can be transacted before emission reductions are verified.

Sectoral trading means that allowances are issued before or at the beginning of a commitment period, and that operators within the sector can sell their allowances to other operators, potentially also buyers in developed countries if systems are linked. In the case of deforestation, the approach is sectoral, however, the issue of crediting and linking to carbon markets are far from agreed at the international level.

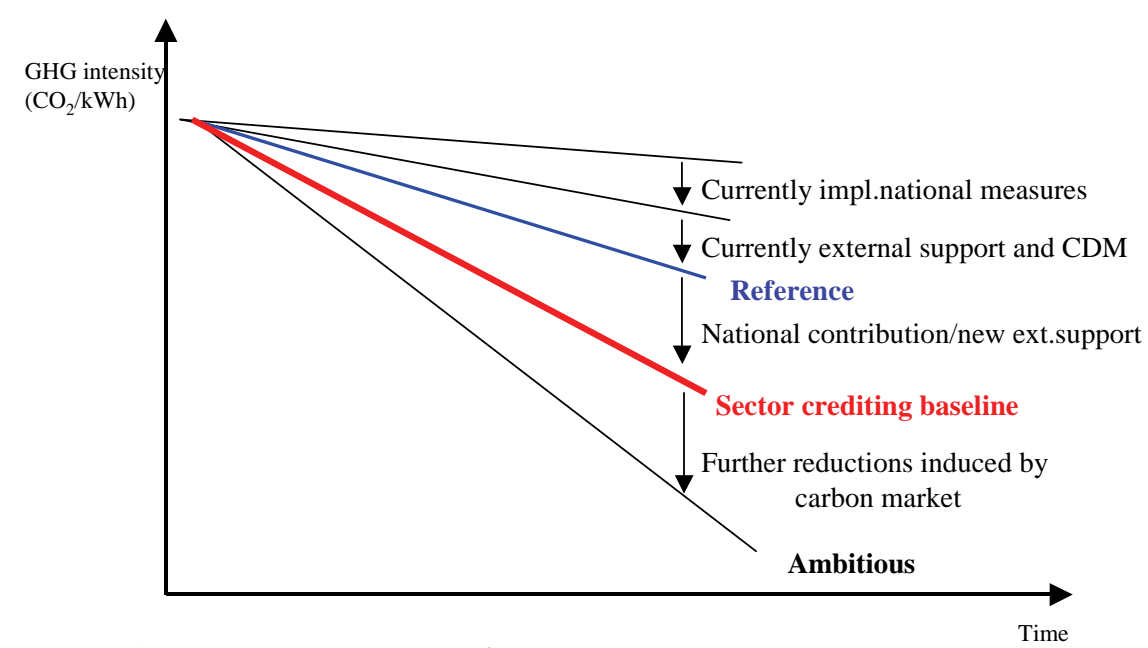

Figure 10. EU's view on Sector Crediting

\subsubsection{Negotiations on Sectoral or NAMA crediting}

In the process towards Copenhagen, several proposals for a framework of sectoral mechanisms were submitted. The mechanisms proposed sectoral or NAMA crediting and sectoral trading.

The Republic of Korea, the European Union and New Zealand made proposals for crediting and trading.

One of the basic ideas from the EU proposal is that the developing country should address the reduction potential below a reference level without the involvement of carbon finance, and that international funding efforts could be 
used to reduce emissions further, before any crediting can take place. Whereas Korea's and New Zealand's proposal fully allude to voluntary participation, the EU:s idea is more based on political high level agreements.

Another difference between the proposals concerns the reference level. With the concept of NAMAs, developing countries are expected to reduce emissions and measure and report these reductions. A reference level should then take into considerations activities already planned plus NAMAs that are supported, i.e. financed by public finance from developed countries (including development assistance). According to Korea any emission reductions below these two aspects of the reference level, would be eligible for crediting.

However, in EU's and New Zealand's proposals, the reference level should be set further below in order to provide for a net emission reduction effect beyond offsetting. It would be in the interest of the participating sector and the host country government to push the reference level upwards, thus, establishing a system in which the reference level is agreed or assessed internationally will be a tricky part of the legal text for these mechanisms.

All proposals consider some international supervision.

A future regime framework is also likely to specify participation requirements, e.g. a national system of inventory and reporting, perhaps to a lower quality than what currently is needed for Annex-I Parties. A NAMA or sectoral crediting mechanism within the frame of the UNFCCC would take considerable time to negotiate and a full-scale operation is not likely before 2020.

\subsubsection{How Well Does the NAMA Concept Work with the Idea of Sectoral Crediting?}

The coupling between NAMA and crediting is not obvious from a developing country perspective. The reason is that a NAMA should be something country specific, not determined or approved by international supervision, although possibly presented in an international NAMA registry, and that there is no obligation guiding the implementation of the NAMA from the UNFCCC.

From a developing country point a view "common but differentiated responsibilities" under the Convention does not include the idea that developing countries should finance mitigation actions on their own, but rather that mitigation actions should be financed by developed countries on a full incremental cost basis.

On the one hand, a developing country could be quite content with the conditions and rules set by the UNFCCC and the Kyoto Protocol, and accordingly the developing countries have argued very strongly for the continuation of the Protocol. Furthermore, developing country proposals regarding NAMAs, in particular the EU's, can be understood as imposing Measurement, Reporting and Verification (MRV) requirements and in the end binding sector targets. 
On the other hand, developing country initiatives may provide for a stream of financing and investment and in a bottom up approach climate regime - the situation where the US and other developed countries are collaborating with different countries on a bilateral basis - joint mitigation efforts could be made that would not cohere strictly with the UNFCCC. In this situation, as well as the situation where there is an agreement introducing new mechanisms, implementing NAMAs for which a significant part of the financing includes carbon credits, it would be in the interest of the developing country to establish MRV for the sector, sub-sector or NAMA activities and possibly to fund (or regulate) activities domestically.

In Poznan, Mexico announced that it will pursue a transsector cap-andtrade program to include the electricity, oil, cement, and iron and steel sectors. The initiation was slated for 2011 for cement and refineries (iron and steel may be later).

The example of Mexico shows that advanced developing countries already are taking initiatives in the climate area. Such initiatives include a variety of policies and measures, including sector wide cap and trade schemes.

\subsubsection{Examples and Comments on NAMAs and Sectoral Approaches}

Proposals for new mechanisms have been tabled by a number of Parties to the UNFCCC and several developing countries are considering or preparing for market-based approaches as an option to help meet their domestic mitigation targets. Such examples are India's Perform-Achieve-Trade (PAT), an energy efficiency certificate system as well as the call for low-carbon pilote programmes in China.

OECD and the International Enercy Agency (IEA) presented an Agenda document for the Climate Change Expert Group of the UNFCCC on market readiness, discussing the aspects on market readiness in order to introduce market based mechanisms ${ }^{27}$. The paper considers two catogiries of market mechanisms, namely domestic market mechanisms duch as emissions trading systems, and international crediting mechanisms such as NAMA crediting. The three main categories of market readiness building blocks are:

- Technical readiness, including coverage (sources to be included in the system); reference year emissions, a measurement, reporting and verification (MRV) system; a registry; and a transaction log.

- Policy readiness, including setting the goals and the policy instrument for the distribution of benefits from the carbon market.

Institutional and legal readiness, including new institutions and laws for the operation of the market mechanism.The market-readiness elements will

\footnotetext{
${ }^{27}$ OECD, IEA (2010), Market Readiness: Building blocks for market approaches
} 
probably develop in parallel and OECD/IEA structure the market readiness elements in the figure below.

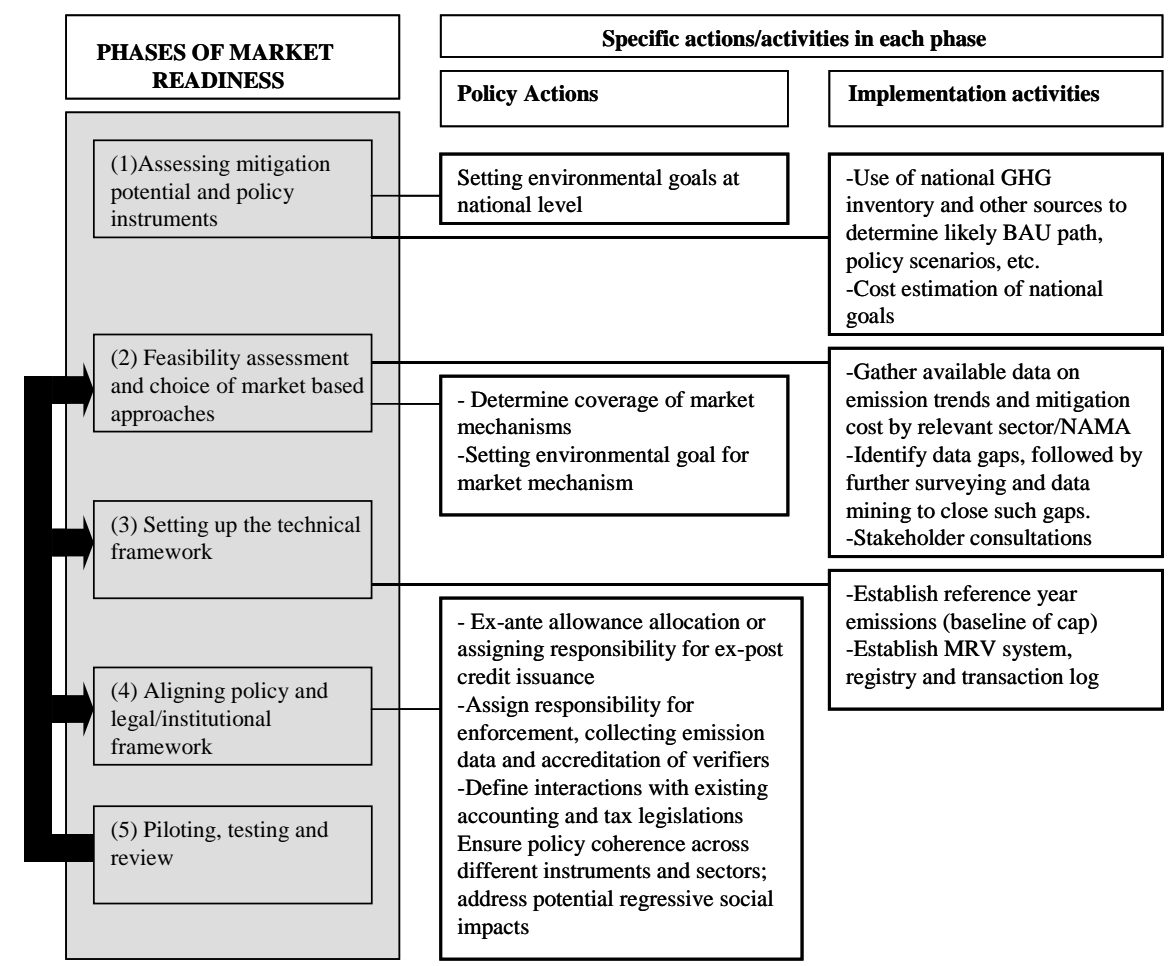

Figure 11. Phases of market readiness. Source: OECD/IEA.

OECD and IEA estimate the need for financing of market readiness to USD $2-5$ billion over the next ten years and parties could reflect on using a portion of the fast-track finance pledged under the Copenhagen Accord for market readiness activities.

The World Bank has taken an initiative to build capacity and create dialogue with respect to carbon market mechanisms by creating the World Bank Partnership for Market Readiness. Among the main objectives of the partnership are: to create a platform to enable policy makers and practioners to share experiences and information regarding elements of market readiness; provide grant financing to the participating countries in building "infrastructure"for market readiness; and pilot and test new concets for market readiness.

The World Bank has also created the Carbon Partnership Facility in order to develop emission reductions and support their purchase over long periods after 2012, as a response to the challenges they identified for many clean long-term investments in energy and infrastructure. The objective and business model of the Carbon Partnership Facility are based on the need to prepare large-scale, potentially risky investments with long lead times, which require durable partnerships between buyers and sellers. The facility aims, thus, to move from individual projects to programmatic approaches. 
The Center for Clean Air Policy has conducted a number of studies on sectoral approaches and NAMAs and concludes the following:

Firstly, good quality data, Measurement Reporting and Verification systems and policy development capacity is needed in all developing countries and must be immediate priority. Secondly, supported sectoral NAMAs will be a first building block for developing country actions The more advanced developing countries are already undertaking unilateral efforts to reduce GHG emissions in key economic sectors. Thirdly, several advanced developing countries are now considering and implementing market-based approaches to energy efficiency and emission mitigation. Finally, supported NAMAs and sectoral crediting can be "bridge strategies" to carbon trading systems and MRV procedures.

The stumbling-blocks on the way to successful implementation of sectoral and/or NAMA crediting mechanisms are several. There is a lack of reliable data to establish baselines and reference levels. Secondly, as pointed out in the Swedish Energy Agency study and by IETA, the designing of these new mechanisms are very important in order to keep and increase the incentive for private sector participation. Implementing these new mechanisms under a common global climate regime will be time consuming and potentially not in operation before 2020 and furthermore, the implementation of an upscaled or sectoral mechanism requires a host country involvement of a much higher degree than in the case of CDM.

In sum, activities in this area is of high priority and while the regulatory framework is still in the starting blocks, pilot activities and collaborative efforts could have a significant positive impact on the negotiation process and the design of the new mechanisms. For instance, the EU Council of Ministers has made the following conclusion:

The Cancún Conference should provide a basis for the introduction of new scaled-up market mechanisms and the recognition of credits resulting from such mechanisms, including through a pilot scheme. 



\section{Forest and plantation related activities to reduce GHG emissions}

Forests play an important role in global carbon budget, acting either as sinks or sources of carbon. The total carbon content of forest ecosystem is estimated to about 638 Gtonnes of Carbon, which is more than the amount of carbon in the atmosphere. Deforestation and forest degradation result in substantial reductions in forest carbon stocks and increase in emissions. The Intergovernmental Panel on Climate Change has estimated emissions from deforestation since $1990 \mathrm{~s}$ at $5.8 \mathrm{GtCO}_{2} / \mathrm{yr}$.

The causes of deforestation vary. Taking Amazonas as an example, during the period 2000-2005, 60\% of deforestation was due to establishment of new cattle ranches, $30 \%$ was caused by small scale subsistence agriculture, legal and illegal logging accounted for $3 \%$ as fires, mining, road construction and dams, and large scale agriculture accounted for $1 \%$.

Conservation and LULUCF activities may have large positive implications for the environment, biodiversity conservation and sustainable development. The costs for mitigation of reduced deforestation vary depending on the (i) cause of deforestation; (ii) returns from alternative forest/non forest uses; (iii) any compensation paid to landowners to change land use practices. The cost of emission reduction for plantation and conservation projects varies between 1 Euro and 5 Euro per tonne $\mathrm{CO}_{2}$. An abatement cost study by consultants McKinsey ${ }^{28}$ suggests costs up to EUR 25 for forest and plantation related activities. Carbon sinks are greenhouse gas removals that can be achieved by land use projects. The Climate Change Convention (UNFCCC) defines "sink" as "any process, activity or mechanism which removes a greenhouse gas, an aerosol or a precursor of a greenhouse gas from the atmosphere". The development of policy on "sinks" has evolved to cover emissions and removals of greenhouse gases resulting from direct human-induced land use, (LULUCF) activities and thus, the acronym LULUCF is now used to refer to this sector. Sinks and forest related project are somewhat integrated to the Kyoto framework:

- Carbon sequestration in forests can be used in countries' accounting when reaching targets in the Kyoto compliance regime.

- The Kyoto framework also provides for JI- as well as CDM-projects using the LULUCF approach.

\footnotetext{
${ }^{28}$ Pathways to a Low-Carbon Economy (2009), p.7
} 
Only one sink project is to date registered by the CDM Executive Board, and only five are reported to be in the pipeline. The complexity of the rule system in relation to the low price of tCERs and lCERs is a main barrier for sink projects in CDM. In addition, the awkward temporary crediting and a competing voluntary market with higher price and lower transaction costs can be mentioned as causes of the lack of sink projects within CDM. Another main reason for the absence of sink projects in CDM is that the demand was significantly reduced when the EU decided not to include these projects in the EU ETS. The incentives for the private sector to engage in sinks in CDM have been very low and the main actor on this market has been the Community Carbon Development Fund and the BioCarbon Fund of the World Bank ${ }^{29}$.

\subsection{REDD and REDD+ in Negotiations}

Avoided deforestation has been discussed during the 90's but did not become part of the Kyoto Protocol because of risks and limitations with regard to monitoring, permanence and leakage. Discussions regarding avoided deforestation or forest conservation have regained a momentum the last years, and has been formalised under "REDD", Reducing Emissions from Deforestation in Developing Countries upon the initiative of amongst others Papa New Guinea and Costa Rica ${ }^{30}$.

Sinks were brought up on the agenda during the creation of the climate change convention (UNFCCC) in the early 1990's. The agenda item on "Reducing emissions from deforestation in developing countries and approaches to stimulate action" was first introduced into the COP (Conference of the Parties of the Convention) agenda at its eleventh session in Montreal (December 2005). This proposal resulted in a COP decision at the Bali meeting where the COP adopted a decision encouraging tropical forest countries to undertake demonstration activities and providing "indicative guidance" for such projects in order for understanding the challenges ahead. The primary focus of the demonstration activities was the development of national emission baselines, based on historic emissions, against which reductions can be measured. The initial decision text leaves open whether incentives to reduce deforestation would take the form of carbon credits or direct financial assistance.

Following the Bali meeting, discussions continued at several meetings during 2008, leading up to COP 14/CMP 4 in Poznan. The negotiations re-

\footnotetext{
${ }^{29}$ The World Bank has mobilized a public/private fund to demonstrate projects that sequester or conserve carbon in forest and agro-ecosystems. The Fund aims to deliver cost-effective emission reductions, while promoting biodiversity conservation and poverty alleviation. The BioCarbon Fund can consider purchasing carbon from a variety of land use and forestry projects; the portfolio includes Afforestation and Reforestation, Reducing Emissions from Deforestation and Degradation and is exploring innovative approaches to agricultural carbon.

${ }^{30}$ Submissions to Conference of the Parties (COP 11) under the UNFCCC
} 
garding policy and regulations for REDD takes place within the frame of AWG LCA (Ad Hoc Working Group on long Term Co-operative action under the Convention). There was no specific outcome beyond an agreement to continue the discussions about REDD during 2009.

The Copenhagen Accord, the non-binding political statement resulting from COP/MOP 15 in Copenhagen stipulates that:

"We recognize the crucial role of reducing emission from deforestation and forest degradation and the need to enhance removals of greenhouse gas emission by forests and agree on the need to provide positive incentives to such actions through the immediate establishment of a mechanism including REDD-plus, to enable the mobilization of financial resources from developed countries.”

Prior to the development of the Accord, however, negotiators in Copenhagen worked on much more detailed REDD+ language (the REDD+ decision text) which they hoped the parties would adopt to further guide the REDD+ discussions. In this text, negotiators had fleshed out much more specific elements of a potential REDD+ decision.

The "+" in REDD+ refers two the second part of the sentence about REDD in the Bali Action Plan. The type of activities recognized as part of a REDD+ system is still not determined and can include conservation of forest stocks, sustainable management of forests, and the enhancement of forest carbon stocks. Whereas the Copenhagen Accord text refers to reducing emissions from deforestation and forest degradation, as well as conservation, it does not make explicit reference to sustainable management and enhancement of carbon stocks.

\subsection{The Future of REDD}

The Copenhagen Accord, like the Bali Action Plan, states that there should be positive financial incentives for countries that take action to reduce deforestation and degradation. However, how countries would receive this money is still up in the air - this could be through a carbon market, a dedicated fund, or through other mechanisms. Financing will be one of the key issues for landing a global REDD regime.

High level decisions on REDD+ are needed as a result from the UNFCCC process and the meeting in Cancun. Issues of MRV, safeguards and methodology need to be solved in order to guide the pilot activities that exist in the area.

Many activities take place outside the UNFCCC process and with only limited guidance from the UNFCCC process. There are initiatives such as the World Bank's Forest Carbon Partnership Facility and Forest Investment Program. Discussions on interim political partnerships - while waiting for the UNFCCC - began in Paris in March 2010 and continued in Oslo in May. 
These pilot programs and interim arrangements will not set the rules for REDD+, but provide lessons learned that are useful for the negotiations.

\subsection{Norway’s Approach to REDD}

At COP 13 in Bali in 2007 Norwegian Prime Minister Stoltenberg pledged up to USD 500 million per year to reduce emissions from forests in developing countries (REDD+). The International Climate and Forest Initiative was subsequently set up with a project team within the Ministry of Environment. The initiative works towards the inclusion of REDD+ in a future climate agreement, to achieve large-scale emission reductions in the short term and to protect natural forests. To achieve this, the initiative has pursued multiple tracks:

First, the Initiative is working for the inclusion of "REDD+" under the UN Framework Convention for Climate Change (UNFCCC). On the 27 May this year, more than 50 countries gathered in Oslo to establish a global partnership on climate and forest, which will improve transparency and coordination of financing in this field. The partnership may also be a stepping stone to agreement on REDD+ in the climate change negotiations. The partnership established in Oslo is the first of its kind, and the first partnership between developed and developing countries in the battle against global warming. Norway has worked actively on international policy development for REDD+, including through its secretariat role of the Informal Working Group for Interim Finance for REDD+, through the REDD Options Assessment Report and other studies.

Second, the initiative has contributed to the design and establishment of an international architecture on REDD+. Norway has pledged several hundred million dollars annually in grants to international REDD efforts. Multilateral channels are considered to be the best and most efficient way of organizing the international efforts to reduce the loss of tropical forests. Therefore, utilizing the competence and capacities possessed by the UN, the World Bank and the regional development banks are core elements of a coordinated international support structure, and essential to succeed in this work.

Third, Norway demonstrates how tropical deforestation can be reduced in practice at a national level, by supporting a few selected countries. To date, Brazil, Indonesia, Guyana and Tanzania have been selected for large scale partnerships. Brazil has reduced its deforestation by $60 \%$ since 2005 . A partnership with Indonesia was established in May this year, and the potential for reduced emissions is tremendous. Indonesia has the largest emissions from deforestation and degradation of forests and tropical peat land in the world. Forests are disappearing at a rate of more than a million hectares per year. $80 \%$ of Indonesia's greenhouse gas emissions currently stem from deforestation and destruction of peat lands.

Lastly, Norway has a long tradition of supporting and cooperating with both NGOs and INGOs, often with extensive knowledge and expertise in 
environmental issues and in direct contact with people affected by deforestation and degradation. Norway finances NGOs, research institutes and civil society organizations to provide analyses and pilot projects on the ground.

In the work to support REDD+ Norway has identified the main challenges:

- Ensuring that the reduction of deforestation takes place and measuring results;

- Ensuring sustainable development, conservation of biodiversity; indigenous people's rights, good governance, and benefit sharing;

- Preventing national and inter-national "leakage".

- Norway has also pointed out some ways of resolving above challenges:

- Early transition to payments for results, i.e., verified emission reduction;

- Using governance measures and stakeholder involvement as criteria for large-scale support;

- Focus on national level strategies with high-level political support; building of capabilities and expertise in the recipient country;

- Systematic cooperation with NGOs, and relevant research institutions;

- Coordination of international efforts;

- Support both high-deforestation countries and those yet to embark on deforestation.

\subsection{Concluding Remarks}

Reducing emissions from deforestation and forest degradation, as well as creating incentives for a sustainable forest management and the enhancement of carbon stocks are essential for reaching the reduction targets proposed by the IPCC.

Norway has taken a leading role in launching REDD pilot activities, particularly through financing initiatives. 



\section{Planned and future collaboration}

\subsection{Nordic Collaboration Aiming at Improving Current Functioning of Mechanisms}

The Nordic countries have been forerunners in the creation of the carbon market, including contributing to the governance of the supervisory bodies of CDM and JI, CDM Executive Board and JI Supervisory Committee. The Nordic countries can also in the future have a place in the driving seat of the carbon market train, either through providing new guidance in order to improve the existing mechanisms or through piloting initiatives with regard to new mechanisms. The representatives from Nordic countries that participated in this project identified following themes on future collaboration in order to improve current mechanisms:

- The participants agreed that there is a need to streamline the CDM, and that the Nordic countries should look into how an effort could be made to further promote standardized baselines.

- The participants also discussed possibilities to share experiences and knowledge regarding "domestic JI" in order to develop the project based mechanism under Article 24 in the EU ETS Directive.

- Furthermore, the participants discussed testing the newly established ProClimate Guarantee Facility with one or several common Nordic project(s) in one or several Least Developed Country(ies).

\subsection{Continued Nordic Collaboration on Sharing of Practical Experiences Related to National Purchase Programmes}

The Nordic CDM- and JI programmes are involved in all aspects of the carbon market, including the development of projects from a Project Idea Note to purchasing through intermediaries or over the counter purchase of CERs. The programme officials collect experience on the development of CDMand JI projects as well as the validation process, the monitoring and verification of projects. Exchanging experiences on bottlenecks, barriers as well as ways of overcoming the barriers enables the Nordic programmes to improve their efficiency and reaching their individual targets. Thus, one possible 
outcome of this project is a continuous exchange of practical experiences between the Nordic JI- and CDM purchase programmes.

\subsection{Nordic Collaboration Aiming at the Development of New Mechanisms}

Since the regulatory framework is still being negotiated and will not be ready by 2012, joint Nordic projects and initiatives may have a significant positive influence in the negotiation process and the design of new mechanisms.

Sector mechanisms refers to an approach where emission reductions under a fixed level are credited to whole sectors of developing countries such as for example the transport sector of Mexico or India. The Nordic Council of Ministers (through the Nordic Ad Hoc Group on Climate Change, NOAK) in cooperation with NEFCO will launch a feasibility study of a pilot, not under the title of a sectoral of NAMA crediting project, but of upscaled sectoral credit mechanisms. The project outline will be presented at COP 16 in Cancun in December 2010 under the title of the NOAK-NEFCO Partnership Initiative. One possibility raisied at the workshop was that a testing facility could be created under the wings of NEFCO in order to buy credits from pilot projects in the area of upscaled mechanisms or sectoral/NAMA crediting.

The Nordic countries envision a pilot programme of preliminary some 25 millions Euros over 2-3 years with a view to a longer term cooperation between the Nordic countries and the host country. The aim of the pilot programme is to demonstrate how broad and up-scaled support can effectively be matched with comprehensive host country mitigation plans.

The first step is a NOAK-NEFCO funded feasibility study with the overall aim to prepare the practical ground for a pilot-project. This feasibility study will be conducted in co-operation with a host country (or host countries) looking at a specific sector or subsectors in that country/ies. Some key points of this study will be:

(i) The feasibility study, jointly developed with the partner host country, should explore and analyze in detail how the Nordic countries can offer a broad range of support to a comprehensive climate mitigation strategy in the host country(ies).

(ii) The types of support analyzed could include both direct financial support and technical support. The support should be linked to nationally appropriate mitigation action in accordance with the Bali Action plan and the Copenhagen Accord and could lead to voluntary/ or new type of carbon market instruments e.g. credits in the longer-term.

(iii) The types of support analyzed should fit in to the climate mitigation strategy proposed by the host country. 


\section{References}

Amin, Amal-Lee (2009), Carbon Finance: Driving Technological Transformation of the Global Economy in IETA Carbon Market 2008

Center for Clean Air Policy (2008), presentation at AWG LCA 4 in Bangkok 2008

Center for Clean Air Policy (2009), Technology-based Sectoral NAMAs: A preliminary case study of china's cement and iron\&steel sectors

Eric Bettelheim (2008), Forest Day II, Poznan Dec 2008

European Parliament and Council (2009), (2008), (2005), (2003) All Directives of the European parliament and of the Council amending Directive 2003/87/EC International Emissions Trading Association (2009), Carbon Market 2008

McKinsey (2009), Pathways to a LowCarbon Economy

NEFCO (2010), The Nordic Climate Guarantee Facility

Nordic Council of Ministers (2010) Report from Workshop 1. Nordic Experiences from the Carbon Market

Nordic Council of Ministers (2010) Report from workshop 2. The Role of Public Finance in the Carbon Market

Nordic Council of Ministers (2010) Report from workshop 3. Perspectives for Future Co-operation on JI/CDM with Focus on Post-2012 and New Mechanisms

Nordic Environment Finance Corporation (2010), Baltic Sea Region Testing Ground Facility (TGF) Review of Experiences and Lessons Learned 2005-2009
OECD, IEA (2010), Market Readiness: Building blocks for market approaches Point Carbon (2010), Carbon Market Analyst 27, 2010

Point Carbon (2010), Outlook for 2010 and Beyond

SEF Alliance (2010), Publicly Backed Guarantees as Policy Instruments to Promote Clean Energy

Trines (2003), Abatement and independent verification costs of sinks CDM projects: An inventory of experience

United Nations Environment Programme (2009), And yet it moves. Success stories and drivers of CDM project development in sub-Saharan Africa

United Nations Environment Programme Risoe (2010), CDM Pipeline Overview

United Nations Environment Programme Risoe (2010), JI Pipeline Overview

United Nations Framework Committee on Climate Change (1997), Kyoto Protocol to the United Nations Framework Convention on Climate Change

United Nations Framework Committee on Climate Change (2005), Submissions to Conference of the Parties. COP 11 Montreal

United Nations Framework Committee on Climate Change (2007), Decision 1/CP.13. Bali Action Plan

United Nations Framework Committee on Climate Change (2009), Investment and Financial Flows to Address Climate Change: An Update

World Bank (2010), State and Trends of the Carbon Market 



\section{Svensk sammanfattning och slutsats}

I augusti 2009 beslutade Nordiska ministerrådet att de nordiska finansministrarna skulle lansera ett gemensamt projekt för de nordiska ländernas erfarenheter från Kyotoprotokollets flexibla mekanismer CDM (Clean Development Mechanism) och JI (Joint Implementation). Projektet initierades mot bakgrund av de förestående förhandlingarna om framtida mekanismer efter 2012, för att ge underlag för diskussioner om möjligheter för de nordiska länderna att delta i en framtida $\mathrm{CO}_{2}$ kreditmarknad. Projektet har genomförts under perioden april till september 2010 och under den perioden har tre workshops genomförts, med deltagare från de nordiska regeringarna, NEFCO, nordiska finans-och utvecklingsinstitut, samt särskilda inbjudna från externa organisationer och företag. Den första workshopen behandlas de erfarenheter från nordiska CDM och JI program, den andra workshopen behandlade hinder mot genom-genomförande CDM och JI-projekt relaterade till finansieringsfrågor, och den tredje workshopen behandlade möjliga framtida flexibla mekanismer, samt en diskussion om framtida samarbete mellan nordiska regeringarna inom ramen för den framtida $\mathrm{CO}_{2}$ kreditmarknaden. Resultatet av dessa tre workshops presenteras i tre separata rapporter från seminarierna, och denna sammanfattande rapport sammanfattar hela projektets resultat.

\section{Nordiskt deltagande på $\mathrm{CO}_{2}$ kreditmarknaden}

Marknaden för $\mathrm{CO}_{2}$ krediter, som bygger på de flexibla mekanismerna i Kyotoprotokollet, har vuxit kraftigt de senaste tio åren. Marknaden som helhet beräknas vara värd $€ 121$ miljarder 2010, vilket motsvarar utsläppsreduktionsenheter på 8,4 Gton $\mathrm{CO}_{2}$-ekvivalenter. EUs handel med utsläppsrätter EU ETS, står för ungefär 75 \% av den volymen.

Den totala mängden CDM-projektbaserade transaktioner under 2009 var 211 miljoner ton $\mathrm{CO}_{2}$ till ett ungefärligt värde av 1916 miljoner Euro, vilket bara var ungefär hälften av värdet av CDM-marknaden under 2008. JIprojektbaserade transaktioner under 2009 var ungefär $13 \%$ av CDMprojekt-transaktionerna, $26 \mathrm{Mt} \mathrm{CO}_{2}$, till ett ungefärligt värde av 252 miljoner Euro.

De nordiska regeringarna har bidragit till utvecklingen av $\mathrm{CO}_{2}$ kreditmarknaden, och i synnerhet till att skapa en fungerande marknad för CER och ERU, som är de utsläppskrediter som härrör från Kyotoprotokollets flexibla mekanismer CDM (Clean Development Mechanism) och JI (Joint 
Implementation). Sammantaget har de nordiska länderna allokerat mer än 1 miljard Euro för köp av CERs och ERUs, och för detta belopp till inköp programmen räkna med att få en total av 60-75 miljoner CERs och/eller ERUs. De nordiska CDM-och JI programmen har varit kostnadseffektiva komplement till nationella strategier för klimatförändring.

De statliga programmen har bidragit till att utveckla marknaden för projekbaserade mekanismer och byggt upp förtroendet för marknaden, vilket har banat väg för att privata företag, konsulter och mäklare sedan kommit in på marknaden. Insatserna har bestått av olika aktiviteter:

- De nordiska regeringarna var bland de första att engagera sig i olika tidiga projektbaserade $\mathrm{CO}_{2}$ kreditfonder som var bland de första att identifiera av projekt, utveckla av nya metoder, och sprida kunskap om CDM globalt. Bland dessa fonder kan nämnas särskilt Världsbankens Prototype Carbon Fund, som var den första lanserade fonden för projektbaserade $\mathrm{CO}_{2}$ krediter, och Baltic Sea Testing Ground Facility, TGF, som förvaltas av NEFCO,

- De nordiska regeringarna var bland de första att etablera egna CDM och JI-program. Finland upprättade, som första nordiska land, ett program för föregångaren till de flexibla mekanismerna 1999, följt Sverige 2002, Danmark 2003 och Norge 2007. Flera nordiska länder var således tidiga med att identifiera och utveckla CDM-och JI-projekt, under en tid då processen var osäker och få exempel på framgång fanns tillgängliga;

- De nordiska regeringarna har genomfört flera program för kapacitetsuppbyggnad i syfte att öka antalet CDM och JI-projekt i länder som är eller har varit underrepresenterade på $\mathrm{CO}_{2}$ kreditmarknaden.

Syftet med de Nordiska CDM och JI programmen skiljer sig något från varandra. Målet med det svenska programmet är inte att förvärva en viss volym utsläppsreduktionsenheter, medan programmen i de övriga nordiska länderna har sådana volymmål. Danmark och Finland förvärvar utsläppsreduktionssenheter för att uppfylla sina åtaganden enligt Kyotoprotokollet. Norge köper $\mathrm{CO}_{2}$ krediter för att överskrida sina åtaganden enligt Kyotoprotokollet med $10 \%$. Sverige räknar med att uppfylla sina åtaganden enligt Kyotoprotokollet utan att använda utsläppsreduktionsenheter, men kan utnyttja dessa krediter för att möta framtida åtaganden. Målet för det svenska programmet för köp är således mer kvalitativt än kvantitativt, och stödjer utvecklingen av en global marknad, geografiskt spridd med särskild inriktning på de minst utvecklade länderna och små ö-nationer.

De metoder som används för inköp varierar mellan de nordiska länderna och NEFCO, och tjänstemännen med ansvar för JI och CDM programmen har utbytt erfarenheter om hinder och olika sätt att överbrygga hindren i alla delar av JI / CDM projektcykeln.

Inom ramen för erfarenhetsutbytet har lärdomar kommunicerats inom en mängd områden, såsom vikten av att använda nätverk av organisationer som 
ambassader, statliga investeringsfonder, CDM / JI-utvecklare (dvs. privata företag specialiserade på utveckling av CDM- / JI-projekt eller investeringar), vikten av goda förbindelser med nationella myndigheter i värdlandet, mäklare, finansiella institutioner och validerare. Ett etablerat nätverk och gott rykte är mycket viktigt för att identifiera och utveckla CDM- och JIprojekt. Till exempel berodde NEFCOs relativa framgång i de baltiska länderna på långvarig närvaro och gott rykte på marknaden. Vanligen upplevda hinder var ofta relaterade till validering och registrering samt verifiering och utfärdandet av krediter, men även genomförandet av småskaliga projekt i de minst utvecklade länderna.

Samtliga program hade haft hinder i fråga om de underliggande finansieringen av projekt, t.ex. hade det visat sig vara utmanande för projektägare att använda köpeavtalet, Emission Reduction Purchase Agreement, som säkerhet för lån eller bankgarantier för förskottsbetalningar, särskilt för projekt ägare i de minst utvecklade länderna. Behovet av förskottsbetalning är särskilt stor i projekt för förnybar energi, eftersom dessa projekt ofta kräver en stor investering innan kassaflödet från energi/el-generering och CER leverans inträffar. Sammanfattningsvis har programmen bidragit till att bygga upp den internationella $\mathrm{CO}_{2}$ kreditmarknaden, och programmen har bidragit med värdefulla insikter till regeringarna, insikter som kan användas i de internationella klimatförhandlingarna om nya mekanismer. Samarbetet mellan de nordiska länderna i frågor $\mathrm{CO}_{2}$ kredit marknaden har skapat en bra nordisk plattform i de internationella klimatförhandlingarna. CDM- och JI- Programmen är också ett kostnadseffektivt sätt för länderna att uppfylla sina åtaganden enligt Kyotoprotokollet och för Norge ett sätt att nå nationella mål som går längre än åtagandena enligt Kyotoprotokollet. Samtidigt ger programmen stöd för tekniköverföring och hållbar utveckling i värdländerna.

\section{Utveckla och förbättra offentlig finansiering av CDM- projekt}

Investeringskostnaderna för CDM-projekt utvecklingsländer består av eget kapital och skulder som i alla projekt som inte omfattar CDM finansiering. Genom CDM och JI kan projektägare få ytterligare bidrag till den totala finansieringen av projekten. Den ekonomiska ersättningen består i allmänhet av ett extra kassaflöde som betalas regelbundet då projektet tas i kommersiell drift, men kan i vissa fall delvis betalas i förskott. En projektägare bör kunna använda sitt försäljningskontrakt för sina CDM-eller JI-krediter som säkerhet i låneansökan. Men även om CDM och JI bidrar till den totala finansieringen av projekten finns i allmänhet alltid ett behov av ett första anslag, dvs eget kapital och lån, vilket bara delvis kan lösas av CDM och JI. Sammantaget kan CDM och JI ensamt endast i begränsad omfattning öka antalet genomförda projekt i regioner och länder där investeringsklimatet är dåligt, i de minst utvecklade länderna (LDCs, Least Developed Countries). 
Offentlig finansiering, t.ex. från multilaterala fonder eller genom bilaterala biståndet kan lätta de stränga krav på avkastning av privat kapital och kan ta större risk. Offentliga finansieringsinstitut har därför en viktig och betydelsefull roll både för kapacitetsuppbyggnad, projektutveckling och riskhantering, i form av garantier. Förskottsfinansiering har inte ökat markant med CDM. Offentlig finansiering kan bidra till att öka utbudet av hållbara projekt i underrepresenterade sektorer och länder och därigenom stärka intresset från privata investerare att agera i nya regioner samt nya typer projekt på $\mathrm{CO}_{2}$ kreditmarknaden.

Det av Nordic Development Fund, NDF, nyligen inrättade ProClimate Facility, är ett initiativ för att ge garantier som förbättrar det ekonomiska utnyttjandet av köpekontrakt av $\mathrm{CO}_{2}$ krediter. Det rekommenteras att de nordiska länderna inleder ett CDM-pilotprojekt i ett ekonomiskt svagt utvecklat afrikanskt land (LDC) för att pröva ProClimate garantin.

Offentliga finanser kan spela en viktig roll för att förbättra JI / CDM, vilket gör marknaderna mer effektiva, och bryter ny mark för CDM i de minst utvecklade länderna.

\section{Utveckla och förstärka befintliga och nya mekanismer i en efter 2012 Period}

Det nuvarande regelverket för handel med utsläppsrätter och projektbaserade mekanismer är grunden för att bilda nya mekanismer. Det andra huvudsakliga grunden är efterfrågan på sektorsbaserade insatser i utvecklingsländer. Den långsamma takten i de internationella förhandlingarna om ett klimatavtal efter 2012 och starka konflikter medför en osäkerhet på $\mathrm{CO}_{2}$ kreditmarknaden. En fortsättning på ett Kyoto-liknande system med CDM och JI samt en bred överenskommelse som nya mekanismer kan dra nytta av utveckling och testning av nya versioner och modeller av projekt-, programeller sektor-eller NAMA mekanismer. Att minska utsläppen från avskogning och skogsförstörelse, samt skapa incitament för ett hållbart skogsbruk och förstärkning av kollager är också viktigt för att nå de minskningsmål föreslagits av IPCC. Norge har tagit en ledande roll i lanseringen REDD pilotprojekt, i synnerhet via finansiering initiativ.

Rent konkret kan de nordiska länderna agera kollektivt inom följande områden:

För det första, CDM och potentiellt även JI kommer att vara mycket viktiga mekanismer under perioden fram till 2020.

EUs reviderade ETS-direktiv (artikel 11a, para.3) tillåter utbyte av såväl CDM-och JI-krediter från projekt registrerade före 2013 som utfärdas från 2013 och framåt. När det gäller ERU, beror fortsatt utfärdande på omvandling av AAU och avsaknaden av en andra åtagandeperiod under Kyotoprotokollet, vilket skulle hindra fortsatt JI-projekt efter 2012. Fortsatt utfärdande av ERU kan dock garanteras efter 2012 genom bilaterala avtal med värd- 
parterna, om dessa inte ingår i EU ETS. ERU kan också genereras om riktlinjer för projekt enligt artikel 24a i EU-ETS-direktivet utarbetas, om projekt befinner sig i EU-länderna och inte omfattas av ETS. Genomförandet av artikel 11a§3 återstår att beslutas av EU-Kommissionen. Initiativ till bilaterala avtal med parter utanför EU-systemet skulle kunna vara ett effektivt sätt att stärka JI efter 2012.

Initiativ som syftar till att förbättra CDM marknadsmässiga villkor kan ha en positiv effekt på antalet nya genomförda projekt och den geografiska spridningen av sådana projekt. Initiativet ProClimate Facility och andra liknande initiativ kan ha en betydande positiv effekt av den finansiella hävstång för CDM avtal samt god grund för det nordiska samarbetet.

Det finns ett behov att göra CDM effektivare. Standardiserade referenslinjer är ett område som kan förstärka CDM och ett område där också de nordiska länderna skulle kunna främja åtgärder genom att stödja utveckling av projekt med hjälp av standarder. Standardisering skulle kunna öka objektiviteten i bevisföringen beträffande om projekten skulle eller inte skulle ha tillkommit utan CDM. Standardisering ökar också objektiviteten, förenklar beräkningen av referenslinjer samt utsläppsberäkningar och övervakning. Standardiserade referenslinjer ses också som ett sätt att säkra den miljömässiga integriteten av CDM och att förbättra den geografiska spridningen av CDM-projektverksamhet.

En metod för standardiserade referensliner skulle kunna fungera inom förnybar energi, transport, jordbruk och energieffektivitet i byggnader sektorer. De olika typerna av standardisering som ska användas kan ordnas under (i) positiv lista, (ii) utsläpp eller riktmärken, (iii) tekniska riktmärken och (iv) standardiserade värden.

Framtida och befintliga program för kapacitetsuppbyggnad som inkluderar nya emissionsfaktorer för elnät är ett annat område som kan förstärka CDM, särskilt i länder som är underrepresenterade på utsläppsmarknaden, och ett område där också de nordiska länderna har en potential att samarbeta:

För det första kan insatser för att effektivisera de befintliga mekanismerna vara ett effektivt sätt att få acceptans för att diskutera nya övergripande mekanismer i UNFCCC.

För det andra, nya uppskalade mekanismer, sektoriella eller NAMA kreditering, kan komma att lanseras inom ramen för en global överenskommelse. Förhoppningen är att villkor och förfaranden för en sådan mekanism kan inrättas inom de närmaste åren, men fullskalig drift av sådana mekanismer inte trolig före 2020. Det finns alltså ett behov av omedelbara åtgärder för att underlätta förhandlingarna och utveckla utformningen av nya mekanismer.

Nya mekanismer skulle behöva anpassas till den politiska och ekonomiska verkligheten i varje land. Det kommer att finnas ett behov av data av god kvalitet, upprättandet av MRV (mätning, rapportering och kontroll) system och politisk vilja i utvecklingsländerna. Flera andra frågor är också viktiga att lösa för ett framgångsrikt genomförande av sektoriella och / eller NAMA mekanismer. Svårigheten att fastställa referensnivåer och referensnivåer 
måste övervinnas och nya mekanismer måste utformas på ett sätt som ökar incitamenten för den privata sektorns deltagande.

Nordiska Ministerrådet (genom Nordiska ad hoc-gruppen för klimatförändringar, NOAK) i samarbete med NEFCO kommer att lansera en pilotstudie, inte med benämningen NAMA kreditering projektet, utan av en uppskalad sektorsmekanism. Projektets utkast kommer att presenteras vid COP $16 \mathrm{i}$ Cancun i december 2010 under titeln i NOAK-NEFCO partnerskapsinitiativet. Ett möjligt område för nordiskt samarbete skulle kunna vara att delta i NOAK som skulle kunna ledas av NEFCO i syfte att köpa krediter från pilotprojekt inom området för uppskalad mekanismer eller sektorskreditering.

Fördelarna med att genomföra nya mekanismer i utvecklingsländer är, förutom bidraget till globalt minskade utsläpp, att utvecklingen av verksamheten i $\mathrm{CO}_{2}$ sektorn kan ge en grund för att stärka utvecklingsländernas förmåga att genomföra miljöpolitik och att föreskriva en övergång till inhemsk utvecklingsåtgärder, inbegripet marknadsbaserade lösningar såsom handelssystem.

Ramen för det framtida nordiska samarbetet är ännu inte fastlagd. Bilaterala diskussioner och informella kontakter skulle kunna utvecklas till en formell grupp för samarbete eller samarbete skulle kunna vara mer ad hoc som en del av verksamhet bedriven av NEFCO. Verksamheten att samarbeta kring är av hög prioritet och då regelverket fortfarande är i startgroparna så kan pilotverksamhet och samarbeten, såsom NOAK-NEFCO partnerskapsinitiativet, ha betydande positiv inverkan på förhandlingsprocessen och utformningen av nya mekanismer. 